\title{
Reviews and syntheses: Turning the challenges of partitioning ecosystem evaporation and transpiration into opportunities
}

Paul C. Stoy ${ }^{1,2}$, Tarek S. El-Madany ${ }^{3}$, Joshua B. Fisher ${ }^{4,5}$, Pierre Gentine $^{6}$, Tobias Gerken ${ }^{7}$, Stephen P. Good $^{8}$, Anne Klosterhalfen ${ }^{9}$, Shuguang Liu ${ }^{10}$, Diego G. Miralles ${ }^{11}$, Oscar Perez-Priego ${ }^{3,12}$, Angela J. Rigden ${ }^{13}$, Todd H. Skaggs ${ }^{14}$, Georg Wohlfahrt ${ }^{15}$, Ray G. Anderson ${ }^{14}$, A. Miriam J. Coenders-Gerrits ${ }^{16}$, Martin Jung ${ }^{3}$, Wouter H. Maes ${ }^{11}$, Ivan Mammarella ${ }^{17}$, Matthias Mauder ${ }^{18}$, Mirco Migliavacca ${ }^{3}$, Jacob A. Nelson ${ }^{3}$, Rafael Poyatos $^{19,20}$, Markus Reichstein ${ }^{3}$, Russell L. Scott ${ }^{21}$, and Sebastian Wolf ${ }^{22}$

${ }^{1}$ Department of Biological Systems Engineering, University of Wisconsin-Madison, Madison, WI 53706, USA

${ }^{2}$ Department of Land Resources and Environmental Sciences, Montana State University, Bozeman, MT 59717, USA

${ }^{3}$ Max Planck Institute for Biogeochemistry, Hans Knöll Straße 10, 07745 Jena, Germany

${ }^{4}$ Jet Propulsion Laboratory, California Institute of Technology, 4800 Oak Grove Drive, Pasadena, CA 91109, USA

${ }^{5}$ Joint Institute for Regional Earth System Science and Engineering, University of California at Los Angeles, Los Angeles, CA 90095, USA

${ }^{6}$ Department of Earth and Environmental Engineering, Columbia University, New York, NY 10027, USA

${ }^{7}$ The Pennsylvania State University, Department of Meteorology and Atmospheric Science, 503 Walker Building, University Park, PA, USA

${ }^{8}$ Department of Biological \& Ecological Engineering, Oregon State University, Corvallis, Oregon, USA

${ }^{9}$ Agrosphere Institute, IBG-3, Forschungszentrum Jülich GmbH, 52425 Jülich, Germany

${ }^{10}$ National Engineering Laboratory for Applied Technology of Forestry and Ecology in South China, Central South University of Forestry and Technology, Changsha, China

${ }^{11}$ Laboratory of Hydrology and Water Management, Ghent University, Coupure Links 653, 9000 Gent, Belgium

${ }^{12}$ Department of Biological Sciences, Macquarie University, North Ryde, NSW 2109, Australia

${ }^{13}$ Department of Earth and Planetary Sciences, Harvard University, Cambridge, MA 02138, USA

${ }^{14}$ U.S. Salinity Laboratory, USDA-ARS, Riverside, CA, USA

${ }^{15}$ Institut für Ökologie, Universität Innsbruck, Sternwartestr. 15, 6020 Innsbruck, Austria

${ }^{16}$ Water Resources Section, Delft University of Technology, Stevinweg 1, 2628 CN Delft, the Netherlands

${ }^{17}$ Institute for Atmospheric and Earth System Research/Physics, Faculty of Science, 00014 University of Helsinki,

Helsinki, Finland

${ }^{18}$ Karlsruhe Institute of Technology, Institute of Meteorology and Climate Research - Atmospheric Environmental Research, Garmisch-Partenkirchen, Germany

${ }^{19}$ CREAF, E08193 Bellaterra (Cerdanyola del Vallès), Catalonia, Spain

${ }^{20}$ Laboratory of Plant Ecology, Faculty of Bioscience Engineering, Ghent University, Coupure links 653 , 9000 Ghent, Belgium

${ }^{21}$ Southwest Watershed Research Center, USDA Agricultural Research Service, Tucson, AZ, USA

${ }^{22}$ Department of Environmental Systems Science, ETH Zurich, Zurich, Switzerland

Correspondence: Tarek S. El-Madany (telmad@bgc-jena.mpg.de)

Received: 7 March 2019 - Discussion started: 12 March 2019

Revised: 20 August 2019 - Accepted: 22 August 2019 - Published: 1 October 2019 
Abstract. Evaporation $(E)$ and transpiration $(T)$ respond differently to ongoing changes in climate, atmospheric composition, and land use. It is difficult to partition ecosystem-scale evapotranspiration (ET) measurements into $E$ and $T$, which makes it difficult to validate satellite data and land surface models. Here, we review current progress in partitioning $E$ and $T$ and provide a prospectus for how to improve theory and observations going forward. Recent advancements in analytical techniques create new opportunities for partitioning $E$ and $T$ at the ecosystem scale, but their assumptions have yet to be fully tested. For example, many approaches to partition $E$ and $T$ rely on the notion that plant canopy conductance and ecosystem water use efficiency exhibit optimal responses to atmospheric vapor pressure deficit $(D)$. We use observations from 240 eddy covariance flux towers to demonstrate that optimal ecosystem response to $D$ is a reasonable assumption, in agreement with recent studies, but more analysis is necessary to determine the conditions for which this assumption holds. Another critical assumption for many partitioning approaches is that ET can be approximated as $T$ during ideal transpiring conditions, which has been challenged by observational studies. We demonstrate that $T$ can exceed $95 \%$ of ET from certain ecosystems, but other ecosystems do not appear to reach this value, which suggests that this assumption is ecosystem-dependent with implications for partitioning. It is important to further improve approaches for partitioning $E$ and $T$, yet few multi-method comparisons have been undertaken to date. Advances in our understanding of carbon-water coupling at the stomatal, leaf, and canopy level open new perspectives on how to quantify $T$ via its strong coupling with photosynthesis. Photosynthesis can be constrained at the ecosystem and global scales with emerging data sources including solar-induced fluorescence, carbonyl sulfide flux measurements, thermography, and more. Such comparisons would improve our mechanistic understanding of ecosystem water fluxes and provide the observations necessary to validate remote sensing algorithms and land surface models to understand the changing global water cycle.

\section{Introduction}

Some $70000 \mathrm{~km}^{3}$ of water leaves terrestrial ecosystems and enters the atmosphere through evapotranspiration (ET) every year (Jung et al., 2019; Oki and Kanae, 2006). Despite its importance, we are unsure whether global ET has been increasing over time (Brutsaert, 2013, 2017; Brutsaert and Parlange, 1998; Zeng et al., 2018; Zhang et al., 2016) such that the water cycle is accelerating (Ohmura and Wild, 2002) or decreasing and causing more river discharge (Gedney et al., 2006; Labat et al., 2004; Probst and Tardy, 1987). Global ET volumes from reanalyses, upscaled estimates, and land surface model (LSM) outputs disagree (Mueller et al., 2013) by up to $50 \%$ (Mao et al., 2015; Vinukollu et al., 2011). LSMs also struggle to simulate the magnitude and/or seasonality of ET at the ecosystem scale (Fig. 1), suggesting fundamental gaps in our understanding of the terrestrial water cycle. These issues need to be resolved to effectively manage water resources as climate continues to change (Dolman et al., 2014; Fisher et al., 2017).

Along with technological and data limitations, we argue that a fundamental challenge in modeling ET at the global scale is difficulty measuring transpiration $(T)$ through plant stomata and evaporation $(E)$ from non-stomatal surfaces at the ecosystem scale (Fisher et al., 2017; McCabe et al., 2017). LSMs and remote sensing algorithms (see Appendix A) rely on a process-based understanding of $E$ and $T$ to estimate ET, but it is not clear how to guide their improvement without accurate ground-based $E$ and $T$ observations at spatial scales on the order of a few kilometers or less (Talsma et al., 2018) and temporal scales that capture diurnal, seasonal, and interannual variability in water fluxes. Recent statistical ET partitioning approaches (Rigden et al., 2018) are similarly limited by the lack of direct $E$ and $T$ observations for evaluation. Interest in partitioning $E$ and $T$ from ecosystem ET measurements has grown in recent years (Anderson et al., 2017b), and many new measurements and modeling approaches seek to do so but often rely on assumptions that need further testing. We begin with a brief research review that notes recent updates to our theoretical understanding of ET and outlines the challenges in measuring $E$ and $T$ at the ecosystem scale. We then describe current and emerging innovations in partitioning $E$ and $T$ (Table 1) and use observations to challenge some of the assumptions upon which these approaches rely. We finish with an outlook of how carefully designed ecosystem-scale experiments can constrain models of $E$ and $T$ to improve our understanding going forward.

\section{Background}

\subsection{Vegetation plays a central role in evaporation and transpiration partitioning}

The ratio of transpiration to evapotranspiration $(T / E T)$ at annual timescales is related to aridity (Good et al., 2017) but appears to be relatively insensitive to annual precipitation $(P)$ (Schlesinger and Jasechko, 2014). $T$ /ET is sensitive to ecosystem characteristics, namely the leaf area index (LAI) (Berkelhammer et al., 2016; Fatichi and Pappas, 2017; Wang et al., 2014; Wei et al., 2015), especially on sub-annual timescales (Li et al., 2019; Scott and Biederman, 2017), noting that LAI is related to $P$ at longer timescales. A higher LAI favors $T$ and $E$ from intercepted water $\left(E_{\mathrm{i}}\right)$ at the expense of $E$ from soil ( $\left.E_{\text {soil }}\right)$ such that LAI explains some $43 \%$ of the variability of annual $T$ / ET across global ecosystems (Wang et al., 2014). Upscaling this relationship results in a global estimate of terrestrial annual $T / \mathrm{ET}$ of $0.57 \pm 0.07$ 

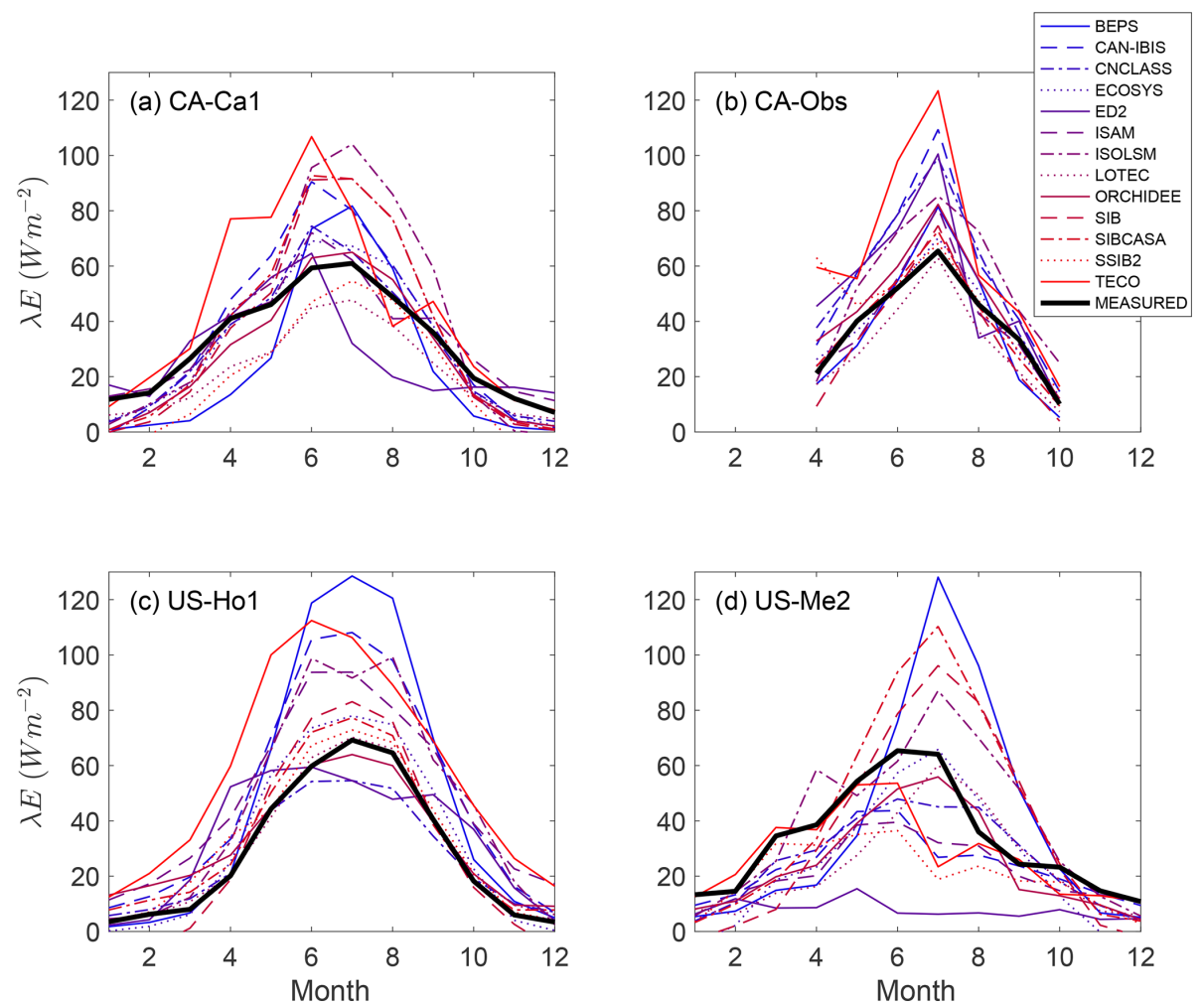

Figure 1. The mean monthly latent heat flux $(\lambda E)$ - the energy used for evapotranspiration - from eddy covariance measurements from four research sites ("MEASURED") and 13 ecosystem models from the North American Carbon Program Site-Level Interim Synthesis (Schwalm et al., 2010). Sites: CA-Ca1 (Schwalm et al., 2007), CA-Obs (Griffis et al., 2003; Jarvis et al., 1997), US-Ho1 (Hollinger et al., 1999), USMe2 (Thomas et al., 2009). Models: BEPS (Liu et al., 1999), CAN-IBIS (Williamson et al., 2008), CNCLASS (Arain et al., 2006), ECOSYS (Grant et al., 2005), ED2 (Medvigy et al., 2009), ISAM (Jain and Yang, 2005), ISOLSM (Riley et al., 2002), LOTEC (Hanson et al., 2004), ORCHIDEE (Krinner et al., 2005), SIB (Baker et al., 2008), SIBCASA (Schaefer et al., 2009), SSIB2 (Zhan et al., 2003), TECO (Weng and Luo, 2008). Data are available from Ricciuto et al. (2013).

(Wei et al., 2017). Other observational studies suggest that annual $T$ /ET averages nearly $2 / 3$ globally $(0.61 \pm 0.15$, Schlesinger and Jasechko, 2014; $0.64 \pm 0.13$, Good et al., 2015; and $0.66 \pm 0.13$ across some FLUXNET sites, Li et al., 2019). Intercomparison studies agree on the large uncertainty surrounding these estimates, with reported global terrestrial annual $T$ /ET ratios ranging from 0.35 to 0.90 (Coenders-Gerrits et al., 2014; Fatichi and Pappas, 2017; Young-Robertson et al., 2018). Approaches that use stable isotopes tend to produce higher annual $T$ /ET values due to assumptions regarding isotopic fractionation (Jasechko et al., 2013; Sutanto et al., 2014). Some LSM estimates of annual $T$ / ET arrive at larger values on the order of $0.70 \pm 0.09$ (Fatichi and Pappas, 2017; Paschalis et al., 2018), while other LSMs suggest smaller $T$ / ET; for example, $T$ / ET from the IPCC CMIP5 intercomparison ranges from 0.22 to 0.58 (Wei et al., 2017). Constraining these model results with observations results in an estimate similar to observational studies but with reduced uncertainty: $0.62 \pm 0.06$ (Lian et al., 2018). A number of recent studies suggest that a major cause of the discrepancies between observations and LSM predictions of $T$ / ET is the treatment of lateral flow in models (Chang et al., 2018). Explicitly adding lateral flow and groundwater dynamics is critical for accurate $T$ estimation (Maxwell and Condon, 2016), and realistic lateral flow results in lower $E$ (Chang et al., 2018; Ji et al., 2017). Simulating sub-grid water partitioning is often of particular importance during drought (Ji et al., 2017; Shrestha et al., 2018), as is a realistic representation of plant water stress parameters (Fang et al., 2017). In addition to challenges in simulating $T$ / ET across space, we also need to measure and model $T$ / ET correctly at the ecosystem scale across all timescales over which it varies from minutes or less to multiple years or more. For this, an understanding of ecosystem water transport and biological responses to micrometeorological forcing is necessary (Badgley et al., 2015).

\subsection{Turning theory into practice}

Measuring and modeling water fluxes from the surface to the atmosphere at the ecosystem scale across multiple scales in time is a nontrivial challenge. The pools in which water is stored in ecosystems span spatial scales from soil 
Table 1. A summary of recent approaches for estimating transpiration $(T)$ and/or for partitioning evapotranspiration (ET) into evaporation $(E)$ and $T$ at the ecosystem scale. The reader is referred to Kool et al. (2014) for a comprehensive review of $E$ and $T$ measurement methodologies.

\begin{tabular}{|c|c|c|c|}
\hline Approach & Advantages & Disadvantages & Selected references \\
\hline $\begin{array}{l}\text { Flux-variance } \\
\text { similarity }\end{array}$ & $\begin{array}{l}\text { Uses high-frequency eddy covari- } \\
\text { ance data; open-source software is } \\
\text { available }\end{array}$ & $\begin{array}{l}\text { Necessary terms rarely computed } \\
\text { and/or high-frequency data to cal- } \\
\text { culate terms are rarely shared; sen- } \\
\text { sitive to water use efficiency as- } \\
\text { sumptions }\end{array}$ & $\begin{array}{l}\text { Scanlon and Kustas (2010), Scan- } \\
\text { lon and Sahu (2008), Skaggs et al. } \\
(2018)\end{array}$ \\
\hline $\begin{array}{l}\text { Analyses of } \\
\text { half-hourly to } \\
\text { hourly eddy } \\
\text { covariance data }\end{array}$ & $\begin{array}{l}\text { Use widely available eddy covari- } \\
\text { ance data }\end{array}$ & $\begin{array}{l}\text { Often rely on assumptions regard- } \\
\text { ing water use efficiency and the } \\
\text { maximum value of the } T \text { / ET ratio }\end{array}$ & $\begin{array}{l}\text { Berkelhammer et al. (2016), Lin et } \\
\text { al. (2018), Li et al. (2019), Scott } \\
\text { and Biederman (2017), Zhou et al. } \\
\text { (2016) }\end{array}$ \\
\hline $\begin{array}{l}\text { Solar-induced } \\
\text { fluorescence }\end{array}$ & $\begin{array}{l}\text { Measurements are available at } \\
\text { ecosystem to global scales }\end{array}$ & $\begin{array}{l}\text { Relies on an empirical relationship } \\
\text { between } T \text { and gross primary pro- } \\
\text { ductivity; mechanistic link not yet } \\
\text { understood; uncertainty in SIF re- } \\
\text { trieval }\end{array}$ & $\begin{array}{l}\text { Damm et al. (2018), Lu et al. } \\
\text { (2018), Shan et al. (2019) }\end{array}$ \\
\hline $\begin{array}{l}\text { Carbonyl sulfide } \\
\text { (COS) flux }\end{array}$ & $\begin{array}{l}\text { Can be measured using eddy co- } \\
\text { variance techniques to estimate } \\
\text { canopy conductance }\end{array}$ & $\begin{array}{l}\text { COS flux can also arise from non- } \\
\text { stomatal sources }\end{array}$ & $\begin{array}{l}\text { Whelan et al. (2018), Wohlfahrt et } \\
\text { al. (2012) }\end{array}$ \\
\hline $\begin{array}{l}\text { Surface evaporative } \\
\text { capacitance }\end{array}$ & $\begin{array}{l}\text { Based on the theory of } E_{\text {soil }} \text { and can } \\
\text { be estimated using remote sensing }\end{array}$ & Applies only to $E_{\text {soil }}$ & Or and Lehman (2019) \\
\hline
\end{tabular}

pores to forest canopies. Liquid and gaseous water transport occurs through pathways in the soil, xylem, leaves, and plant surfaces that exhibit nonlinear responses to hydroclimatic forcing, which is itself stochastic (Katul et al., 2007, 2012). These complex dynamics of water storage and transport impact the conductance of water between ecosystems and the atmosphere (Mencuccini et al., 2019; Siqueira et al., 2008), and these conductance terms are central to the Penman-Monteith equation, which combines the thermodynamic, aerodynamic, environmental, and biological variables to which ET $\left(\mathrm{m} \mathrm{s}^{-1}\right)$ responds to represent the mass and energy balance of water flux between the land surface and the atmosphere (Monteith, 1965; Penman, 1948):

$\mathrm{ET}=\frac{1}{\rho \lambda} \frac{s\left(R_{\mathrm{n}}-G\right)+\rho_{\mathrm{a}} c_{p} D g_{\mathrm{a}}}{s+\gamma\left(1+\frac{g_{\mathrm{a}}}{g_{\text {surf }}}\right)}$.

In the Penman-Monteith equation, $\lambda$ is the latent heat of vaporization $\left(\mathrm{J} \mathrm{kg}^{-1}\right), \rho$ is the density of water $\left(\mathrm{kg} \mathrm{m}^{-3}\right), s$ is the slope of the saturation vapor pressure function $\left(\mathrm{Pa} \mathrm{K}^{-1}\right)$, $R_{\mathrm{n}}$ is the surface net radiation ( $\mathrm{W} \mathrm{m}^{-2}$ ), $G$ is the ground heat flux $\left(\mathrm{W} \mathrm{m}^{-2}\right), \rho_{\mathrm{a}}$ is dry air density $\left(\mathrm{kg} \mathrm{m}^{-3}\right), c_{p}$ is the specific heat capacity of air $\left(\mathrm{J} \mathrm{kg}^{-1} \mathrm{~K}^{-1}\right), D$ is the vapor pressure deficit $(\mathrm{Pa}), \gamma$ is the psychrometric constant $\left(\mathrm{Pa} \mathrm{K}^{-1}\right)$, $g_{\mathrm{a}}$ is the conductance of the atmosphere, and $g_{\text {surf }}$ is surface conductance to water vapor flux (both $\mathrm{m} \mathrm{s}^{-1}$ ). $g_{\text {surf }}$ is a spatially upscaled effective parameter that includes canopy conductance from stomatal opening $\left(g_{\mathrm{c}}\right)$ associated with $T$, conductance related to soil evaporation $\left(g_{\text {soil }}\right)$ associated with
$E_{\text {soil }}$, and conductance related to plant-intercepted evaporation $\left(g_{\mathrm{i}}\right)$ associated with $E_{\mathrm{i}}$. The combination of $E_{\text {soil }}$ and $E_{\mathrm{i}}$ results in ecosystem-scale $E$. The biological drivers that alter $g_{\mathrm{c}}$ impact $T$, but physical drivers impact both $E$ and $T$. In practice, the Penman-Monteith equation is commonly simplified because of the challenge of correctly simulating all relevant conductances (Maes et al., 2019; Priestley and Taylor, 1972).

The micrometeorological drivers of the Penman-Monteith equation vary within and across plant canopies and landscapes (Jarvis and McNaughton, 1986), as do the turbulent structures that transport water into the atmosphere by which ET can be measured using eddy covariance. Because ET is commonly measured above plant canopies with eddy covariance, micrometeorological variables are commonly measured above plant canopies as well. These measurements do not necessarily reflect micrometeorological conditions at evaporating and transpiring surfaces. For example, characteristic profiles of water vapor concentration in the atmosphere measured above the plant canopy are different from $D$ at the canopy, leaf, and soil levels (De Kauwe et al., 2017; Jarvis and McNaughton, 1986; Lin et al., 2018). Furthermore, the fundamental assumption that $D$ reflects the difference between atmospheric water vapor pressure and saturated conditions within the leaf is challenged by studies demonstrating that leaf vapor pressure need not be saturated (Cernusak et al., 2018). Radiation, temperature, and wind speed also vary throughout plant canopies with consequences for modeling 
$T$ from the canopy and $E$ from the soil and other ecosystem surfaces. The space-time variability of environmental drivers within plant canopies should therefore ideally be measured or simulated to understand how they impact $E$ and $T$, and ecosystem modelers must decide if this canopy-resolved detail is important to simulate in diverse ecosystems (Boulet et al., 1999; Medvigy et al., 2009; Polhamus et al., 2013).

Modeling ET at the ecosystem scale is challenging enough before noting that ongoing changes to the Earth system impact all of the biotic and abiotic variables that determine it. The decline in incident radiation across some regions of the world due largely to anthropogenic aerosols ("global dimming") and subsequent increase since about 1990 ("global brightening") have changed incident radiation and thus $R_{\mathrm{n}}$ at the land surface (Wild et al., 2005). The observed decrease in wind speed ("global stilling") (McVicar et al., 2012a, b) is partly due to increases in surface roughness owing to increases in LAI (Vautard et al., 2010) and has decreased $g_{\mathrm{a}}$, which is a function of wind speed (Campbell and Norman, 1998). Atmospheric heating changes the terms in Eq. (1) that involve temperature, namely $R_{\mathrm{n}}$ (via incident longwave radiation), $\lambda, \gamma$, and $s$, through the Clausius-Clapeyron relation. A warming climate also increases $D$ in the absence of changes in specific humidity, but specific humidity has increased across many global regions (Willett et al., 2008), resulting in complex spatial and temporal changes in $D$ (Ficklin and Novick, 2017). $g_{c}$ is controlled by soil moisture availability (Porporato et al., 2004), plant hydrodynamics (Bohrer et al., 2005; Matheny et al., 2014), and environmental variables including $D$ that result in stomatal closure (Oren et al., 1999) (Fig. 2), which is critical for models to accurately simulate (Rogers et al., 2017). This dependency on $D$ is predicted to become increasingly important as global temperatures continue to rise (Novick et al., 2016), but $D$ is also highly coupled to soil moisture (Zhou et al., 2019), and both depend on ET itself through soil-vegetationatmosphere coupling. Increases in atmospheric $\mathrm{CO}_{2}$ concentration tend to decrease stomatal conductance at the leaf scale (Field et al., 1995) and have been argued to decrease $g_{c}$ on a global scale (Gedney et al., 2006). However, elevated $\mathrm{CO}_{2}$ often favors increases in LAI (e.g., Ellsworth et al., 1996), thus leading to an increase in transpiring area that can support greater $g_{\mathrm{c}}$. Atmospheric pollutants including ozone also impact $g_{\mathrm{c}}$ with important consequences for vegetation function (Hill et al., 1969; Wittig et al., 2007). Water fluxes from the land surface impact atmospheric boundary layer processes including cloud formation, extreme temperatures, and precipitation (Gerken et al., 2018; Lemordant et al., 2016; Lemordant and Gentine, 2018), which feeds back to land surface fluxes in ways that are inherently nonlinear and difficult to simulate (Ruddell et al., 2013). In addition to these highly nonlinear dynamics of the soil-vegetation-atmosphere system, ongoing land use and land cover changes impact vegetation structure and function with important implications for the water cycle. In brief, we need to correctly simulate how

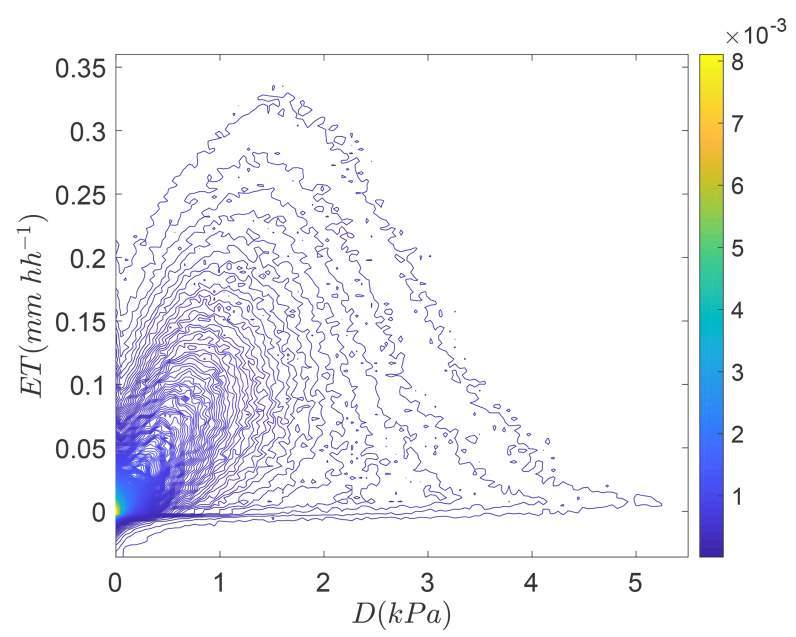

Figure 2. The relationship between above-canopy vapor pressure deficit $(D)$ and evapotranspiration (ET in millimeters per half hour, hh) visualized using kernel density estimation (Botev et al., 2010) for more than 1.5 million half-hourly eddy covariance observations with a solar zenith angle less than $60^{\circ}$ from 241 eddy covariance research sites in the La Thuile FLUXNET database that included ecosystem type and soil heat flux measurements described in Stoy et al. (2013).

$E$ and $T$ respond to a range of biotic and abiotic variability for predictive understanding. To do so, we need to accurately measure $E$ and $T$ in the first place.

\section{Measuring and estimating evaporation and transpiration}

There are multiple established methods to measure ecosystem $E$ and $T$, including leaf gas exchange, plant-level sap flow, lysimeters, soil, leaf, and canopy chambers, photometers, soil heat pulse methods, and stable and radioisotopic techniques. Ongoing efforts to synthesize measurements of ecosystem water cycle components - for example, SAPFLUXNET (Poyatos et al., 2016) - are a promising approach to build an understanding of different terms of the ecosystem water balance across global ecosystems. Multiple reviews and syntheses of $E$ and $T$ measurements have been written (e.g., Abtew and Assefa, 2012; Anderson et al., 2017b; Blyth and Harding, 2011; Kool et al., 2014; Shuttleworth, 2007; Wang and Dickinson, 2012) and have provided the key insights that ecosystem models use to simulate ecosystem-atmosphere water flux (De Kauwe et al., 2013). Rather than reiterate the findings of these studies, we focus on existing and emerging approaches to partition $E$ and $T$ at the ecosystem scale on the order of tens of meters to kilometers at temporal resolutions on the order of minutes to hours, with a particular emphasis on new observational and methodological techniques. We do so to align ecosystem-scale observations of $E$ and $T$ with satellite-based algorithms that 
can scale $E$ and $T$ from ecosystem to region to globe (Appendix A).

ET is commonly approximated as the residual of the water balance at the watershed scale in hydrologic studies - especially when the change in water storage can be assumed to be negligible - but can now be measured using eddy covariance at the ecosystem scale (Wilson et al., 2001). Other approaches including scintillometry (Cammalleri et al., 2010; Hemakumara et al., 2003), surface renewal (Snyder et al., 1996), and the Bowen ratio energy balance method provide important complements to eddy covariance techniques for measuring ecosystem-scale ET. Such syntheses follow ongoing efforts to compile ET measured by eddy covariance via FLUXNET and cooperating consortia (Chu et al., 2017), which synthesize half-hourly to hourly eddy covariance flux measurements that have been used to partition ET into $E$ and $T$ with mixed success.

\subsection{Partitioning ET using half-hourly eddy covariance observations}

An early attempt to partition $E$ and $T$ directly from eddy covariance measurements assumed that ET is comprised solely of $E$ in the absence of canopy photosynthesis (gross primary productivity, GPP) due to the coupled flux of carbon and water through plant stomata (Stoy et al., 2006). It was further assumed that $E_{\text {soil }}$ dominated ET during these times and that $E_{\text {soil }}$ could be modeled by simulating solar radiation attenuation through grass, pine forest, and deciduous forest canopies in the Duke Forest, NC, USA. $T$ was subsequently approximated as the difference between measured ET and the model for $E_{\text {soil }}$ during times when photosynthesis was active. Annual $T$ /ET values from this approach varied from 0.35 to 0.66 in the grass ecosystem (US-Dk1) across a 4-year period and between 0.7 and 0.75 in the pine (US-Dk3) and hardwood (US-Dk2) forests, somewhat higher than global syntheses (Schlesinger and Jasechko, 2014), remote sensing estimates from PT-JPL (see Appendix A) for the Duke pine forest (Fig. 3), and sap-flow-based measurements from the deciduous forest (Oishi et al., 2008). These discrepancies arose in part because $E_{\mathrm{i}}$ was considered negligible but can be considerable (see Sect. 3.6). The model for $E_{\text {soil }}$ could also not be directly validated using measurements from the forest floor alone with available observations.

An under-explored approach for partitioning $E_{\text {soil }}$ from ecosystem ET uses concurrent above- and below-canopy eddy covariance measurements in forest and savanna ecosystems (Misson et al., 2007). Subcanopy eddy covariance measurements have proven useful for measuring below-canopy ET, often assumed to be comprised largely of $E_{\text {soil }}$ in ecosystems with poor understory cover (Baldocchi et al., 1997; Baldocchi and Ryu, 2011; Moore et al., 1996; Sulman et al., 2016). However, such measurements are not yet widely adopted for ET partitioning studies due to a limited understanding of their performance (Perez-Priego et al., 2017);

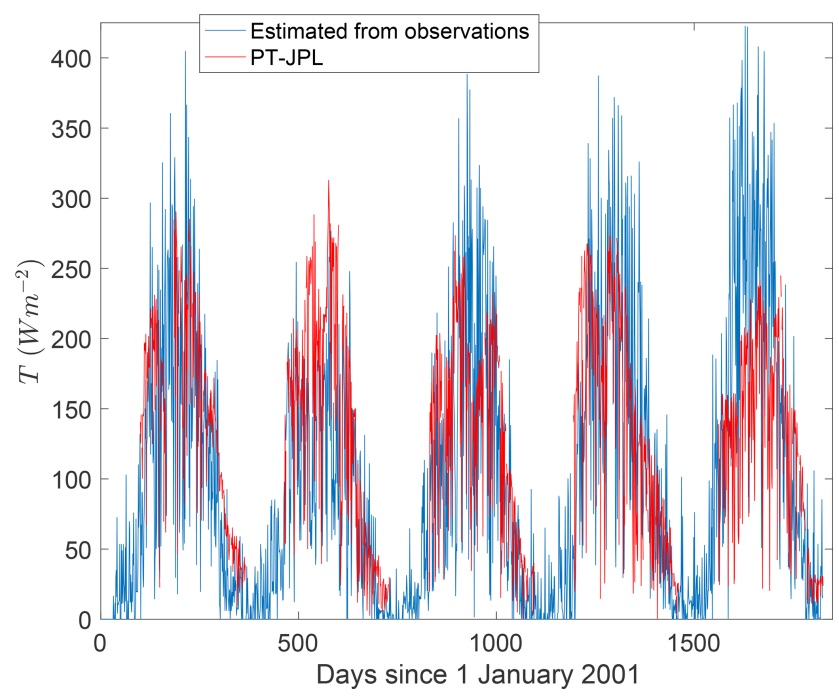

Figure 3. The Priestley-Taylor Jet Propulsion Lab (PT-JPL) estimate of transpiration $(T)$ in energy flux units compared against $T$ estimated using eddy covariance measurements and models of soil evaporation in a loblolly pine forest for 2001-2005 from Stoy et al. (2006). Measurements were taken at 10:30 Eastern Standard Time (UTC-5 h).

most work to date has used below-canopy eddy covariance to partition canopy GPP and soil respiration (Misson et al., 2007). Several recent studies demonstrated the additional value of concurrent below-canopy measurements for quantifying the coupling and decoupling of below- and abovecanopy airspace to accurately apply the eddy covariance technique in forested ecosystems (Jocher et al., 2017, 2018; Paul-Limoges et al., 2017; Thomas et al., 2013), arguing that below-canopy eddy covariance measurements should be more widely adopted. Other eddy-covariance-based partitioning methods take a different approach and use the relationship between $T$ and GPP to partition ecosystem-scale $E$ and $T$.

Scott and Biederman (2017) assumed that $T$ is linearly related to GPP at monthly timescales over many years such that

$T=m_{\mathrm{WUE}} r_{\mathrm{GPP}}$,

where $m_{\text {WUE }}$ is the inverse of the marginal water use efficiency (the change, $\Delta$, in ET per change in GPP: $\Delta \mathrm{ET} / \Delta \mathrm{GPP}$ ), and $r$ is the ratio between the inverse of the transpirational water use efficiency $(\Delta T / \Delta \mathrm{GPP})$ and the marginal ecosystem water use efficiency, which is assumed to be unity. It follows that the intercept $E^{\prime}$ of the relationship $\mathrm{ET}=m_{\mathrm{GPP}}+E^{\prime}$ is an estimate of average monthly $E$. This approach is favored in semiarid ecosystems in which there is a close coupling of ET and GPP and $E$ makes up a considerable amount of monthly ET.

Several recently developed methods for partitioning eddycovariance-measured ET are based on the optimality theory 
assumption that plants minimize water loss per unit of $\mathrm{CO}_{2}$ gain (e.g., Hari et al., 2000; Katul et al., 2009; Medlyn et al., 2011; Schymanski et al., 2007). An outcome of this approach is that plant water use efficiency WUE, defined here as GPP/T, scales with $D^{0.5}$ from which a relationship between GPP and $T$ can be derived (Katul et al., 2009). Berkelhammer et al. (2016) noted that ET follows a linear relationship to GPP $\times D^{0.5}$ and further assumed that the $T / \mathrm{ET}$ ratio intermittently approaches 1 . They then separated ET measurements from eddy covariance into GPP classes for which a minimum ET, $\left.\min (\mathrm{ET})\right|_{\mathrm{GPP}}$, can be defined. $T / \mathrm{ET}$ can then be calculated using

$T / \mathrm{ET}=\frac{\mathrm{ET}}{\left.\min (\mathrm{ET})\right|_{\mathrm{GPP}}}$.

Applying this approach to different forests revealed considerable synoptic-scale variability in $T$ /ET that was dampened at seasonal timescales and compared well against isotopic approaches (Berkelhammer et al., 2016).

Zhou et al. (2016) built upon earlier work (Zhou et al., 2014) and assumed that an ecosystem has an actual underlying water use efficiency ( $\mathrm{uWUE}_{\mathrm{a}}$, where WUE in this case is defined as GPP/ET), which is maximal or reaches its potential underlying water use efficiency $\left(\mathrm{uWUE}_{\mathrm{p}}\right)$ when $T$ /ET approaches unity. $T$ / ET can thus be calculated from the ratio of actual to potential uWUE using optimality assumptions for both:

$\mathrm{uWUE}_{\mathrm{p}}=\frac{\operatorname{GPP} \sqrt{D}}{T}$

and

$\mathrm{uWUE}_{\mathrm{a}}=\frac{\mathrm{GPP} \sqrt{D}}{\mathrm{ET}}$.

Again, assuming that $T$ /ET intermittently approaches 1 in sub-daily eddy covariance measurements, the $\mathrm{uWUE}_{\mathrm{p}}$ can be estimated empirically using 95th quantile regression to find the upper boundary of the relationship between measured ET and GPP $\times D^{0.5}$. uWUE a can be calculated using eddy covariance observations, and $T$ estimates using this approach compare well against independent sap flow measurements (Zhou et al., 2018) and expected responses to drought (Han et al., 2018). A semiempirical model based on the uWUE concept by Boese et al. (2017) included radiation and was able to outperform the Zhou et al. (2016) approach, on average, consistent with the notion that $T$ is also driven by radiation (Eq. 1) (Pieruschka et al., 2010). It is important to note when applying WUE-based approaches that there are important discrepancies between WUE measurements at the leaf and canopy scales that still need to be resolved (Medlyn et al., 2017; Medrano et al., 2015) and also that GPP estimates from eddy covariance observations may have considerable uncertainty.
In a more sophisticated attempt to partition ET utilizing optimality theory, Perez-Priego et al. (2018) utilized a bigleaf canopy model in which parameters were optimized using half-hourly data in 5-day windows. Uniquely, the marginal carbon cost of water was factored into the cost function during parameter estimation, so the parameters for each 5-day window maximized the fit between modeled and observed GPP and also minimized water loss per carbon gain. $T$ was then calculated using $g_{\mathrm{c}}$ from the model, and $E$ was calculated as the residual $(\mathrm{ET}-T)$.

A modified (in this case binned) parameter optimization approach was used by Li et al. (2019) to estimate $g_{\text {surf }}$, which follows the model proposed by Lin et al. (2018):

$g_{\text {surf }}=g_{0}+g_{1} \frac{\mathrm{GPP}}{D_{\mathrm{L}}^{m}}$.

Here, $g_{0}$ (assumed to correspond to soil conductance), $g_{1}$ (assumed to correspond to vegetation conductance), and $m$ are optimized parameters, $D_{\mathrm{L}}$ is the inferred leaf-level $D$, and $g_{\text {surf }}$ is estimated by inverting Eq. (1) and is assumed to represent ecosystem conductance to water vapor flux. Rather than optimizing using a moving window over time, data were binned using independent soil moisture data associated with the eddy covariance site, with $g_{0}, g_{1}$, and $m$ optimized in each bin to account for changes due to water limitations. Partitioning was then calculated as

$\frac{T}{\text { ET }}=\frac{g_{1}}{g_{\text {surf }}}$

and

$\frac{E}{\text { ET }}=\frac{g_{0}}{g_{\text {surf }}}$.

The Perez-Priego et al. (2018) and Li et al. (2019) methods both circumvent the assumption that $T$ / ET approaches unity at some periods by estimating ecosystem conductances directly. The transpiration estimation algorithm (TEA) from Nelson et al. (2018) utilizes a nonparametric model and thereby further limits assumptions made about how the ecosystem functions. However, TEA must make the assumption that $T$ /ET approaches 1, which it does by removing observations when the surface is likely to be wet. In a validation study that utilized model output as synthetic eddy covariance datasets in which $E$ and $T$ are known, TEA was able to predict $T$ /ET patterns in both space and time but showed a sensitivity to the minimum modeled $E$. Overall, TEA was able to predict temporal patterns of $T$ across three different ecosystem models and provides an important basis for comparison because the model for $T$ is agnostic to underlying ecosystem function.

\subsection{Partitioning ET using high-frequency eddy covariance observations}

Scanlon and Kustas (2010) (see also Scanlon and Sahu, 2008) developed a partitioning approach for $E$ and $T$ us- 
ing high-frequency eddy covariance measurements based on the notion that atmospheric eddies transporting $\mathrm{CO}_{2}$ and water vapor from stomatal processes ( $T$ and net primary production; NPP $=$ GPP - aboveground respiration by the autotrophic canopy) and non-stomatal processes ( $E$ and soil respiration) independently follow flux-variance similarity as predicted by Monin-Obukhov similarity theory. In brief, there are two end-member scenarios for a parcel of air transported from a surface: one without stomata and one with stomata. An eddy transported away from a surface that is respiring $\mathrm{CO}_{2}$ and evaporating water through pathways other than stomata will have deviations from the mean $\mathrm{CO}_{2}$ mixing ratio $\left(c^{\prime}\right)$ and water vapor mixing ratio $\left(q^{\prime}\right)$ that are positively correlated. An eddy of air transported by a surface with stomata will have a negative relationship between $c^{\prime}$ and $q^{\prime}$ due to $\mathrm{CO}_{2}$ uptake and $T$ during daytime, whose ratio can also be described by a unique WUE at the leaf level. This leaf-level WUE is thereby used to establish a functional relationship between the variance of $\mathrm{CO}_{2}$ due to stomatal uptake $\left(\sigma_{\mathrm{cp}}^{2}\right)$ and the correlation between stomatal and non-stomatal $\mathrm{CO}_{2}$ exchange processes $\left(\rho_{\mathrm{cp}, \mathrm{cr}}\right)$. Subsequently, ET can be partitioned into its $T$ and $E$ components by matching the observed correlation of $q^{\prime}$ and $c^{\prime}\left(\rho_{q, c}\right)$ to the corresponding value of $\rho_{\text {cp,cr }}$ (Scanlon and Sahu, 2008). The original approach applied wavelet filtering to remove large-scale atmospheric effects that impact the validity of underlying fluxvariance relationships and was shown to realistically reproduce $T$ / ET relationships over the growing period of a corn (maize) crop (Scanlon and Kustas, 2012).

Subsequent work by Skaggs et al. (2018) noted that there is an algebraic solution to terms that had previously been solved using optimization (namely $\sigma_{\mathrm{cp}}^{2}$ and $\rho_{\mathrm{cp}, \mathrm{cr}}$; Palatella et al., 2014) and created an open-source Python module, fluxpart, to calculate $E$ and $T$ using the flux-variance similarity approach. The first applications of the flux-variance similarity approach used a leaf-level WUE formulation following Campbell and Norman (1998); fluxpart allows leaflevel WUE to vary as a function of $D$ or take a constant value. Leaf-level WUE varies throughout the canopy and in response to other environmental conditions. Using high-frequency measurements above the canopy rather than leaf-level observations to estimate it results in uncertainties (Perez-Priego et al., 2018). These uncertainties in leaf-level WUE can be addressed in part by using outgoing longwave radiative flux density observations to estimate canopy temperature (Klosterhalfen et al., 2019a, b). A careful comparison of flux-variance partitioning results against fluxes simulated by large eddy simulation revealed that it yields better results with a developed plant canopy with a clear separation of $\mathrm{CO}_{2}$ and water vapor sources and sinks (Klosterhalfen et al., $2019 \mathrm{~b}$ ). It is also possible to separate $E$ and $T$ using conditional sampling of turbulent eddies (Thomas et al., 2008); the performance of the conditional sampling method is a function of canopy height and leaf area index, and the performance of the flux-variance similarity method is related to the ratio between sensor height and canopy height (Klosterhalfen et al., 2019a), suggesting that different methods may deliver better results in different ecosystems with differing measurement setups.

It should also be noted that flux-variance similarity can be used directly with (half-)hourly flux data if the wavelet filtering step is negligible (necessary variables of each time period are the $\mathrm{CO}_{2}$ and water vapor flux, their respective variances $\left(\sigma_{c}^{2}, \sigma_{q}^{2}\right), \rho_{q, c}$, and an estimated leaf-level WUE), but in practice high-frequency eddy covariance data are required because the necessary terms are rarely computed and saved. Of course, all eddy-covariance-based ET partitioning approaches need to (i) take decoupling between atmosphere, canopy, and subcanopy into account (e.g., Jocher et al., 2017); (ii) critique the energy balance closure of the observations (Leuning et al., 2012; Stoy et al., 2013; Wohlfahrt et al., 2009), especially in closed-path eddy covariance systems that are prone to water vapor attenuation in the inlet tube (Fratini et al., 2012; Mammarella et al., 2009); and (iii) acknowledge the uncertainty of eddy-covariance-based GPP estimates. An advantage of eddy-covariance-based approaches to partition $E$ and $T$ is that they can be complemented by other new approaches that measure or estimate $E$ and $T$ at temporal scales that align with the common halfhourly or hourly eddy covariance averaging period and spatial scales that align with the eddy covariance flux footprint.

\subsection{Solar-induced fluorescence (SIF)}

GPP and $T$ are coupled through stomatal function, and studies of GPP have recently been revolutionized by spaceand ground-based observations of solar-induced fluorescence (SIF) (Frankenberg et al., 2011; Gu et al., 2018; Köhler et al., 2018; Meroni et al., 2009), the process by which some of the incoming radiation that is absorbed by the leaf is reemitted by chlorophyll. SIF emission is related to the light reactions of photosynthesis, but GPP estimation also requires information on the dark reactions and stomatal conductance such that the remote sensing community is currently challenged by how to use SIF to estimate GPP. New studies also propose that SIF might be used to monitor $T$, possibly in combination with surface temperature measurements, acknowledging the close link between GPP and $T$ due to their joint dependence on stomatal conductance and common meteorological and environmental drivers (Alemohammad et al., 2017; Damm et al., 2018; Lu et al., 2018; Pagán et al., 2019; Shan et al., 2019).

While SIF is related to the electron transport rate (Zhang et al., 2014), $T$ primarily depends on stomatal conductance such that SIF and $T$ are linked empirically but not mechanistically. This link is expected if GPP and $T$ are tightly coupled. SIF has also been proposed to predict the ecosystem-scale WUE (i.e., GPP/T) (Lu et al., 2018), a critical component of many of the $E$ and $T$ partitioning algorithms based on the eddy covariance ET measurements described above. Shan et al. (2019) showed that $T$ can be empirically derived from SIF 
in forest and crop ecosystems, with explained total variance ranging from 0.57 to 0.83 , and to a lesser extent in grasslands with explained variance between 0.13 and 0.22 . The authors suggested that the decoupling between GPP and $T$ during water stress hampered the use of SIF to predict $T$, particularly in grasslands, noting that $T$ can occur without GPP under periods of plant stress (Bunce, 1988; De Kauwe et al., 2019). There is a strong empirical link between the ratio of $T$ over potential evaporation and the ratio of SIF over PAR, and the relationship depends on the atmospheric demand for water, with larger transpiration for the same SIF when potential evaporation is higher (Alemohammad et al., 2017; Damm et al., 2018; Lu et al., 2018; Pagán et al., 2019; Shan et al., 2019). These ratios vary with assumptions regarding the potential evaporation calculation as well (Fisher et al., 2010). SIF can be measured at multiple spatial and temporal scales (Köhler et al., 2018), including the scale of the eddy covariance flux footprint (Gu et al., 2018), and this information can in turn be incorporated into remote-sensing-based approaches for estimating ET using remote sensing platforms (see Appendix A) following additional mechanistic studies of its relationship with $T$.

\subsection{Carbonyl sulfide (COS) flux}

Other approaches to estimate GPP and $g_{\text {c }}$ use independent tracers such as carbonyl sulfide (COS). When plants open their stomata to take up $\mathrm{CO}_{2}$ for photosynthesis, they also take up COS (Campbell et al., 2008), a trace gas present in the atmosphere at a global average mole fraction of $\sim 500 \mathrm{ppt}$ (Montzka et al., 2007). The leaf-scale uptake of COS, $F_{\mathrm{COS}}$ $\left(\right.$ pmol m$\left.{ }^{-2} \mathrm{~s}^{-1}\right)$, can be calculated using

$F_{\mathrm{COS}}=-C_{\mathrm{COS}}\left(\frac{1}{g_{\mathrm{b}}}+\frac{1}{g_{\mathrm{s}, \mathrm{COS}}}+\frac{1}{g_{\mathrm{i}}}\right)^{-1}$,

where $C_{\mathrm{COS}}\left(\mathrm{pmol} \mathrm{mol}^{-1}\right)$ is mole fraction of COS and $g_{\mathrm{b}}, g_{\mathrm{s}, \mathrm{COS}}$, and $g_{\mathrm{i}}$ represent the leaf-scale boundary layer, stomatal, and internal conductances (here $\mathrm{mol} \mathrm{m}^{-2} \mathrm{~s}^{-1}$ ) to COS exchange (Sandoval-Soto et al., 2005; Wohlfahrt et al., 2012). The latter lumps together the mesophyll conductance and the biochemical "conductance" imposed by the reaction rate of carbonic anhydrase, the enzyme ultimately responsible for the destruction of COS (Wehr et al., 2017). Equation (9) also makes the common assumption that, because the carbonic anhydrase is highly efficient in catalyzing COS, the COS mole fraction at the diffusion end point is effectively zero (Protoschill-Krebs et al., 1996). Provided appropriate vertical integration over the canopy is made, Eq. (9) can be used to describe canopy-scale $F_{\mathrm{COS}}$ (Wehr et al., 2017).

Because $\mathrm{COS}$ and $\mathrm{CO}_{2}$ share a similar diffusion pathway into leaves and because the leaf exchange of COS is generally unidirectional, COS has been suggested (Sandoval-Soto et al., 2005; Seibt et al., 2010; Wohlfahrt et al., 2012) and demonstrated (Wehr et al., 2017; Yang et al., 2018; Spielmann et al., 2019) to present an independent proxy for esti- mating GPP. Motivated by the common boundary layer and stomatal conductances, there has been recent interest in using measurements of the COS exchange to estimate the canopy stomatal conductance to water vapor and by extension $T$ (Asaf et al., 2013; Wehr et al., 2017; Yang et al., 2018). Solving for $g_{\mathrm{s}, \mathrm{COS}}$ from Eq. (9) requires measurements of $F_{\mathrm{COS}}$ (e.g., by means of eddy covariance; Gerdel et al., 2017) and $C_{\mathrm{COS}}$, while $g_{\mathrm{b}}$ and $g_{\mathrm{i}}$ are typically estimated based on models.

With $g_{\mathrm{s}}$ (and by canopy scaling $g_{\mathrm{c}}$ ) determined this way and an estimate of aerodynamic conductance (the canopy analog to the leaf boundary layer conductance; Eq. 1), $T$ may be derived by multiplication with the canopy-integrated leaf-to-air water vapor gradient. The first and to date only study to attempt this was conducted by Wehr et al. (2017), who demonstrated excellent correspondence with $g_{\mathrm{c}}$ estimated from ET measurements in a temperate deciduous forest. While stomata dominated the limitation of the COS uptake during most of the day, co-limitation by the biochemical "conductance" imposed by carbonic anhydrase was observed around noon. This finding is consistent with leaf-level studies by Sun et al. (2018) and suggests that $g_{i}$ in Eq. (9) may not generally be negligible, even though Yang et al. (2018) found the bulk surface conductance of COS (i.e., all conductance terms in Eq. 9 lumped together) to correspond well with the surface conductance for water vapor inferred from ET. As soils may both emit and take up COS, ecosystem-scale COS flux measurements need to account for any soil exchange, even though typically the soil contribution is small (Maseyk et al., 2014; Whelan et al., 2018). One notable exception for larger soil $F_{\mathrm{COS}}$ fluxes occurs in some agricultural systems (Whelan et al., 2016) due in part to the relationship of $F_{\mathrm{COS}}$ with soil nitrogen (Kaisermann et al., 2018). Clearly, further studies are required in order to establish whether the complexities of and uncertainties associated with inferring $g_{\mathrm{s}}$ from Eq. (9) and non-stomatal fluxes make COS observations a sensible independent alternative for estimating canopy $T$.

\subsection{Advances in thermal imaging}

Thermal remote sensing measures the radiometric surface temperature following the Stefan-Boltzmann law. ET can be estimated using thermal remote sensing by applying an ecosystem energy balance residual approach: $\lambda E=R_{\mathrm{n}}-G-$ $H$ (Norman et al., 1995). Quantifying the available energy term $\left(R_{\mathrm{n}}-G\right)$ is difficult from space, and the radiometric surface temperature measured by infrared sensors is different from the aerodynamic surface temperature that gives rise to sensible heat flux $(H)$ (Kustas and Norman, 1996). Despite these challenges, thermal remote sensing for ET has been widely used with multiple satellite platforms including Landsat, MODIS, Sentinel, and GOES (Anderson et al., 2012; Fisher et al., 2017; Semmens et al., 2016). One of NASA's newest missions is ECOSTRESS, mounted on the Interna- 
tional Space Station, which produces thermally derived ET at $70 \mathrm{~m}$ resolution with diurnal sampling (Fisher et al., 2017).

Advances in thermal imaging (thermography) have made it possible to make radiometric surface temperature observations at increasingly fine spatial and temporal resolutions (Jones, 2004), on the order of millimeters or less, such that $E$ and $T$ can be measured individually from the surfaces from which they arise. Thermography has been used to estimate $E_{\text {soil }}$ (Haghighi and Or, 2015; Nachshon et al., 2011; Shahraeeni and Or, 2010) and $T$ from plant canopies (Jones, 1999; Jones et al., 2002), often in agricultural settings (Ishimwe et al., 2014; Vadivambal and Jayas, 2010). Researchers are increasingly using tower and UAV-mounted thermal cameras to measure the temperatures of different ecosystem components at high temporal and spatial resolution (Hoffmann et al., 2016; Pau et al., 2018), which could revolutionize the measurement of $T$ from plant canopies (Aubrecht et al., 2016) or even individual leaves in a field setting (Page et al., 2018). Such measurements need to consider simultaneous $E_{\mathrm{i}}$ and $T$ from wet leaf surfaces.

\subsection{The challenges of measuring evaporation from canopy interception}

$E_{\mathrm{i}}$ from wet canopies can return $15 \%-30 \%$ or more of incident precipitation back into the atmosphere annually (Crockford and Richardson, 2000), and models struggle to simulate it accurately (De Kauwe et al., 2013). Although interception has been studied for over a century, the underlying physical processes, atmospheric conditions, and canopy characteristics that affect it are poorly understood (van Dijk et al., $2015)$. Accurately estimating $E_{\mathrm{i}}$ from wet canopies is critical for the proper simulation of interception loss (Pereira et al., 2016). However, $E_{\mathrm{i}}$ predicted by the Penman-Monteith equation (Eq. 1) during rainfall is often a factor of 2 or more smaller than the $E_{\mathrm{i}}$ derived from canopy water budget measurements (Schellekens et al., 1999). A recent study using detailed meteorological measurements from a flux tower indicates that the underestimated $E_{\mathrm{i}}$ by the Penman-Monteith equation might be attributed to the failure in accounting for the downward sensible heat flux and heat release from canopy biomass, which can be major energy sources for wetcanopy $E$ (Cisneros Vaca et al., 2018). Storm characteristics (e.g., amount, storm duration, and intensity) and canopy structural information (e.g., canopy openness, canopy storage capacity) are all important parameters for modeling $E_{\mathrm{i}}$ (van Dijk et al., 2015; Linhoss and Siegert, 2016; Wohlfahrt et al., 2006). To partition total ET into $T, E_{\text {soil }}$, and $E_{\mathrm{i}}$, it is necessary to simulate the dynamics of canopy wetness before, during, and after each storm so that models can be applied to the dry and wet portions of the canopy, respectively (Liu et al., 1998), a process that can be implemented using a running canopy water balance model (Liu, 2001; Rutter et al., 1971; Wang et al., 2007). Understanding the sources of water is therefore useful for quantifying differences among
$T, E_{\text {soil }}$, and $E_{\mathrm{i}}$, and information from water isotopes can be helpful to do so.

\subsection{Isotopic approaches}

The hydrogen and oxygen atoms of water molecules exist in multiple isotopic forms, including ${ }^{2} \mathrm{H}$ and ${ }^{18} \mathrm{O}$, which are stable in the environment and can be used to trace the movement of water through hydrologic pathways (Bowen and Good, 2015; Gat, 1996; Good et al., 2015; Kendall and McDonnell, 2012). Because heavier atoms preferentially remain in the more condensed form during phase change, evaporation enriches soils in ${ }^{2} \mathrm{H}$ and ${ }^{18} \mathrm{O}$ (Allison and Barnes, 1983), while root water uptake typically removes water from the soil without changing its isotope ratio (Flanagan and Ehleringer, 1991). This difference in the isotope ratio, $R=\left[{ }^{2} \mathrm{H}\right] /\left[{ }^{1} \mathrm{H}\right]$ or $\left[{ }^{18} \mathrm{O}\right] /\left[{ }^{16} \mathrm{O}\right]$, of $E_{\text {soil }}$ compared with the isotope ratio of water moving through plants is the basis for the isotopic partitioning of ET. If ET consists of two components, $E$ and $T$, with distinct isotopic composition $-R_{\mathrm{E}}$ for soil evaporation and $R_{\mathrm{T}}$ for plant transpiration - then the bulk flux, $R_{\mathrm{ET}}$, can be incorporated into a simple mass balance of the rate isotope (i.e., $R_{\mathrm{ET}} \mathrm{ET}=R_{\mathrm{E}} E+R_{\mathrm{T}} T$ ), which can be rearranged as (Yakir and Sternberg, 2000)

$$
\frac{T}{\mathrm{ET}}=\frac{R_{\mathrm{ET}}-R_{\mathrm{E}}}{R_{\mathrm{T}}-R_{\mathrm{E}}} .
$$

Thus, knowledge of the isotopic ratio of each flux component, $R_{\mathrm{E}}$ and $R_{\mathrm{T}}$, as well as the total bulk flux isotope ratio, $R_{\mathrm{ET}}$, is sufficient to estimate the fraction that passes through plants.

Techniques to measure $R_{\mathrm{ET}}$ have diversified since the widespread deployment of laser-based integrated cavity output spectroscopy (ICOS) systems, which currently monitor atmospheric stable isotope ratios, $R_{\mathrm{A}}$, at a wide number of sites (Wei et al., 2019; Welp et al., 2012). Vertical profiles and high-frequency measurements of $R_{\mathrm{A}}$ are used to determine $R_{\text {ET }}$ using multiple methods, all of which are associated with potentially large uncertainty (Griffis et al., 2005, 2010; Keeling, 1958). Propagation of uncertainties through Eq. (10) demonstrates that errors in $R_{\mathrm{ET}}, R_{\mathrm{T}}$, and $R_{\mathrm{E}}$, as well as differences between $R_{\mathrm{E}}$ and $R_{\mathrm{T}}$, strongly influence the final partitioning estimate (Good et al., 2014; Phillips and Gregg, 2001). The isotopic approach becomes uninformative as $R_{\mathrm{E}}$ approaches $R_{\mathrm{T}}$. Furthermore, as $E_{\mathrm{i}}$ adds another source term to the isotope mass balance, Eq. (10) can be implemented over short periods only when the canopy is dry. If $E_{\mathrm{i}}$ is incorporated as a third source, its magnitude and isotope ratio must be specified, and these assumptions can strongly influence any final isotope-based partitioning estimates (Coenders-Gerrits et al., 2014; Schlesinger and Jasechko, 2014).

The value of $R_{\mathrm{E}}$ is derived from the soil water isotope ratio, $R_{\mathrm{S}}$, as well as the temperature and humidity conditions under which evaporation happened (Craig and Gordon, 
1965). The destructive extraction of water from soil cores can be used to estimate $R_{\mathrm{S}}$, though recent studies have highlighted discrepancies between methodologies (Orlowski et al., 2016a, b). In situ monitoring of $R_{\mathrm{S}}$ obtained by pumping soil vapor through ICOS systems has been demonstrated (Gaj et al., 2016; Oerter et al., 2016; Volkmann and Weiler, 2014) and recently applied to ET partitioning to provide continuous updates on soil isotope ratios (Quade et al., 2019). Eddy covariance measurements of ${ }^{2} \mathrm{H}$ and ${ }^{18} \mathrm{O}$ are now possible (Braden-Behrens et al., 2019). However, identifying $R_{\mathrm{S}}$ remains challenging, and the bulk soil moisture composition (Mathieu and Bariac, 1996; Soderberg et al., 2013), depth (Braud et al., 2005), and soil physical composition (Oerter et al., 2014) at which evaporation occurs can alter the $R_{\mathrm{S}}$ to $R_{\mathrm{E}}$ relationship.

If water entering the plant is isotopically the same as transpired water, known as the isotopic steady-state assumption, then $R_{\mathrm{T}}=R_{\mathrm{S}}$. However, preferential uptake at the root-soil interface, differences between plant internal water pools in time, and mixing along the water pathways within plants will invalidate the steady-state assumption (Farquhar and Cernusak, 2005; Ogée et al., 2007). Finally, variability between and within plant species and plant-soil microclimates of an ecosystem will move the system away from the simple twosource model used in Eq. (10). Accurate knowledge of the isotope ratio within various water reservoirs of a landscape, including the planetary boundary layer (Noone et al., 2013), and how these translate into distinct water fluxes is required to advanced isotope-based partitioning approaches.

\subsection{Statistical approaches}

In addition to modeling $g_{\text {surf }}$ as the sum of $g_{\mathrm{c}}, g_{\text {soil }}$, and $g_{1}$, daily $g_{\text {surf }}$ can also be well-approximated using emergent relationships between the atmospheric boundary layer and land surface fluxes, as demonstrated by the Evapotranspiration from Relative Humidity in Equilibrium (ETRHEQ) method (Rigden and Salvucci, 2015; Salvucci and Gentine, 2013). The ETRHEQ method is based on the hypothesis that the best-fit daily $g_{\text {surf }}$ minimizes the vertical variance of relative humidity averaged over the day. Estimates of ET from this approach compare favorably to eddy covariance measurements (Gentine et al., 2016; Rigden and Salvucci, 2016), and the method can be applied at weather stations due to its primary dependence on meteorological observations. Rigden et al. (2018) recently developed a statistical approach to decompose estimates of $g_{\text {surf }}$ from ETRHEQ into $g_{\mathrm{c}}$ and $g_{\text {soil }}$, allowing ET to be partitioned to $T$ and $E$. The partitioning approach is based on the assumption that vegetation and soil respond independently to environmental variations and utilizes estimates of $g_{\text {surf }}$ at $\sim 1600$ US weather stations, meteorological observations, and satellite retrievals of soil moisture. Estimates of $T$ from this statistical approach show strong agreement with SIF and realistic dry-down dynamics across the US (Rigden et al., 2018); however, the method lacks evaluation with $E$ and $T$ observations directly. Fortunately for many of the techniques discussed above, new large-scale methods for estimating $E_{\text {soil }}$ based on theory have recently been developed and applied at large scales.

\subsection{Novel approaches for estimating soil evaporation}

$E_{\text {soil }}$ is conventionally measured using lysimeters (Black et al., 1969), with some promising results from carefully designed chamber approaches that seek to minimize the impacts of the rapidly humidifying within-chamber atmosphere on evaporation (Raz-Yaseef et al., 2010; Yepez et al., 2005). $E_{\text {soil }}$ has received extensive theoretical treatment (e.g., Brutsaert, 2014) that has resulted in models that align well with observations on ecosystem scales (e.g., Perez-Priego et al., 2018; Lehmann et al., 2018; Merlin et al., 2016, 2018). Lehmann et al. (2018) defined a new model for soil evaporative resistance that correctly describes the transition from stage-I evaporation (non-diffusion limited) to stage-II evaporation (diffusion limited). The model was able to correctly describe the soil moisture dependence of $E_{\text {soil }}$ across different soil types. This approach was extended by Or and Lehmann (2019), who developed a conceptual model for soil evaporation called the surface evaporative capacitance (SEC) model for $E_{\text {soil }}$. Briefly, the transition between stage-I evaporation of a drying soil with capillary flow from deep moisture sources and stage-II evaporation characterized by water vapor diffusion is modeled using an evaporation characteristic length that differs by soil type (Lehmann et al., 2008, 2018). The SEC model accurately simulated $E_{\text {soil }}$ datasets from different global regions, and adding global maps of precipitation and soil properties creates spatially distributed $E_{\text {soil }}$ estimates to model global $E_{\text {soil }}$. The SEC model can be used in combination with other remotely sensed ET estimates (e.g., GLEAM; Appendix A) to partition ET.

\section{Critiquing the assumptions of ET partitioning methods}

\subsection{Do ecosystems exhibit optimal responses to $D$ ?}

Many WUE-based approaches for partitioning $E$ and $T$ (Sect. 3.1 and 3.2) hinge on the notion that $g_{c}$ follows an optimal response to $D$. Recent data-driven studies have argued that $g_{\mathrm{c}}$ measured using eddy covariance is "slightly suboptimal", averaging between $D^{1}$ and $D^{0.5}$ with a mean of $D^{0.55}$ rather than $D^{0.5}$ (Lin et al., 2018), or is "nearly optimal" and scales with GPP $\times D^{0.55}$ (Zhou et al., 2015). Here, we test the assumption that plant canopies exhibit optimal responses to $D$ by assuming that it serves as a constraint on WUE following an implication of optimality theory that 1 minus the ratio of leaf-internal $\mathrm{CO}_{2}\left(c_{\mathrm{i}}\right)$ to atmospheric $\mathrm{CO}_{2}\left(c_{\mathrm{a}}\right), 1-c_{\mathrm{i}} / c_{\mathrm{a}}$, also scales with $D^{0.5}$ (see Eq. 18 in Katul et al., 2009). Using the definition of WUE as GPP / $T$, expanding GPP and $T$ using Fick's law, and excluding differences in mesophyll 
conductance,

$\frac{\mathrm{GPP}}{T}=\frac{g_{\mathrm{c}} \varepsilon c_{\mathrm{a}}\left(1-\frac{c_{\mathrm{i}}}{c_{\mathrm{a}}}\right)}{g_{\mathrm{c}} D}$.

In this equation, $g_{c}$ cancels and $\varepsilon$ is the relative diffusivity of $\mathrm{H}_{2} \mathrm{O}$ and $\mathrm{CO}_{2}$ molecules. If $\left(1-c_{\mathrm{i}} / c_{\mathrm{a}}\right)$ scales with $D^{0.5}$, eddy-covariance-estimated WUE (i.e., GPP / ET) should therefore scale with $D^{-0.5}$ if it can be assumed that measured ET approaches $T$. We tested this notion using micrometeorological and eddy covariance data from 240 sites that include ecosystem type and ecosystem energy balance measurements in the La Thuile FLUXNET database following Stoy et al. (2013). We assumed that $E$ is a trivial component of ET when WUE values exceed $95 \%$ of observations (Zhou et al., 2016) and use a boundary line analysis commonly used in studies of leaf and canopy conductance (Schäfer, 2011) to describe this $95 \%$ threshold. We then took the mean of the upper $95 \%$ of eddy covariance WUE observations in $0.3 \mathrm{kPa}$ bins of $D$ and fit an exponential model to these observations using nonlinear least squares (Fig. 4a) rather than fitting a linear model following log transformation for values that approach zero. Using this approach, we arrive at a mean ( \pm standard deviation) exponential term of $-0.53 \pm 0.17$ from the 240 sites (Fig. 4b), which is not significantly different from -0.5 using a one-sample $t$ test. Repeating this analysis with the FLUXNET2015 dataset reveals a mean exponential term of $-0.49 \pm 0.15$, which is likewise not different from -0.5 .

Land surface models struggle to simulate this emergent property of ecosystems. Models for the ecosystems shown in Fig. 1 tend to dramatically overpredict the magnitude of the exponential term with a mean value of -2.9 (Table 2). The exponential term of the BEPS model was $-0.54 \pm 0.06$, similar to observations. Combined, these results suggest that an optimal canopy response to $D$ may be a reasonable assumption despite the challenges of leaf-to-ecosystem scaling and despite the use of above-canopy rather than $D_{\mathrm{L}}$ here, but the considerable variability of the calculated exponential terms suggests that more research is necessary to understand conditions under which optimality is a reasonable assumption and when it is not. The discrepancy in calculated exponential terms between measurements and models further emphasizes the importance of improved carbon and water coupling in ecosystem models.

\subsection{Does T / ET approach unity?}

Also central to many $E$ and $T$ partitioning approaches is the notion that $T$ / ET intermittently approaches 1 (Berkelhammer et al., 2016; Nelson et al., 2018; Zhou et al., 2016; Wei et al., 2017), as suggested by modeling analyses and measurements (Wei et al., 2015, 2018). This assumption was critiqued by Perez-Priego et al. (2018), who demonstrated that $T$ / ET was rarely greater than 0.8 in a Mediterranean ecosystem, even during dry periods when surface soil moisture was
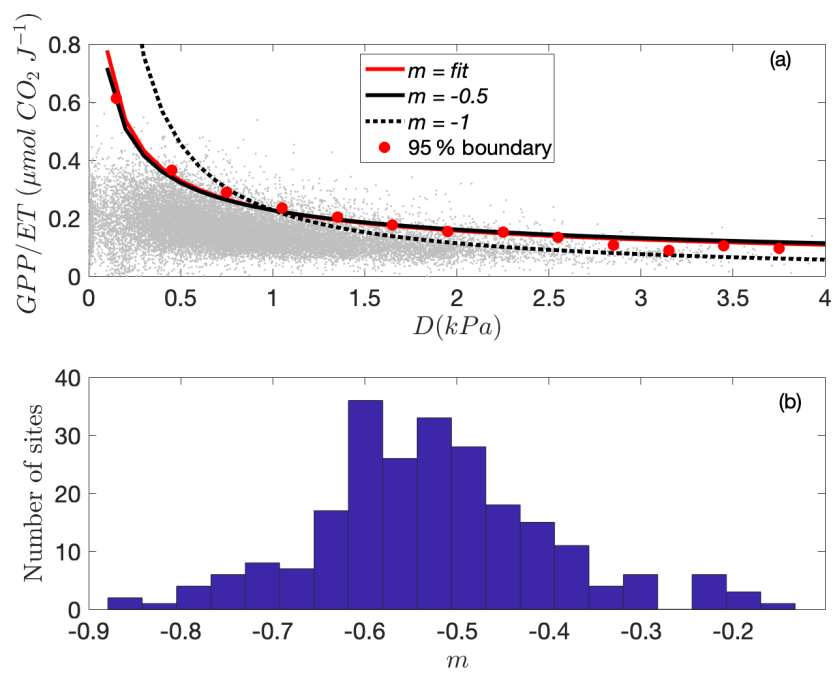

Figure 4. (a) An example of a boundary line analysis to quantify the relationship between vapor pressure deficit $(D)$ and ecosystem water use efficiency defined as gross primary productivity (GPP) divided by evapotranspiration (ET) for the case of a single ecosystem in the La Thuile FLUXNET database, in this case Vielsalm, Belgium (BE-Vie), using GPP/ET values that represent the 95th percentile of $0.3 \mathrm{kPa} D$ bins, shown as red dots. The model $\mathrm{GPP} / \mathrm{ET}=k D^{m}$, fit using nonlinear least squares, is shown as a red line. The value of $m$ for BE-Vie is -0.53 ; the values $m=-0.5$ following Medlyn et al. (2011) and $m=-1$ following Leuning (1995) are shown for reference with the same fitted value of $k$. Individual half-hourly eddy covariance measurements are shown in light gray. (b) The distribution of the best-fit exponential parameter $(m)$ for 240 sites in the La Thuile FLUXNET database that contained the full energy balance measurements and ecosystem type information used in Stoy et al. (2013).

less than $0.2 \mathrm{~m}^{3} \mathrm{~m}^{-3}$, and that $E$ scaled with time ${ }^{-0.5}$ following Brutsaert (2014) (see also Boese et al., 2019, and Li et al., 2019). These findings of a sustained evaporation component and nonzero $E / E T$ even during dry conditions were also supported by lysimeter measurements in a semiarid grassland (Moran et al., 2009) and partly confirmed by a recent study based on isotopes in shrubs and a steppe ecosystem (Wang et al., 2018). The maximum daily $T$ / ET found by Scanlon and Kustas (2012) in a maize agroecosystem was also about 0.8 , but Rana et al. (2018) found daily values that intermittently exceeded 0.9 in wheat and fava bean fields, and multi-method comparisons suggest that $T$ / ET often approaches 0.85 (Rafi et al., 2019). Anderson et al. (2017a) found that $T$ / ET routinely exceeded 0.9 in sugarcane, with maximum daily values above 0.95 , and $\mathrm{Li}$ et al. (2019) also found values greater than 0.9 for other crops. We can critique the notion that $T$ /ET approaches 1 by applying the fluxvariance similarity partitioning approach to a wheat canopy from central Montana, USA, measured by Vick et al. (2016). Wheat has a characteristically high surface conductance (Bonan, 2008) and approaches an ideal transpiring surface dur- 
Table 2. The exponential term $(m)$ of the model WUE $=k D^{m}$ fit using nonlinear least squares to the 95th percentile of WUE values in $0.3 \mathrm{kPa}$ bins of $D$ (see Fig. 4). Sites: CA-Ca1 (Schwalm et al., 2007), CA-Obs (Griffis et al., 2003; Jarvis et al., 1997), US-Ho1 (Hollinger et al., 1999). Models: BEPS (Liu et al., 1999), CANIBIS (Williamson et al., 2008), CNCLASS (Arain et al., 2006), ECOSYS (Grant et al., 2005), ED2 (Medvigy et al., 2009), ISAM , ISOLSM (Riley et al., 2002), LOTEC (Hanson et al., 2004), ORCHIDEE (Krinner et al., 2005), SIB (Baker et al., 2008), SIBCASA (Schaefer et al., 2009), SSIB2 (Zhan et al., 2003), TECO (Weng and Luo, 2008). Data are available from Ricciuto et al. (2013).

\begin{tabular}{lrrr}
\hline Model & CACa1 & CAObs & USHo1 \\
\hline BEPS & -0.6 & -0.5 & -0.5 \\
CAN-IBIS & -4.8 & -2.5 & -4.7 \\
CNCLASS & -3.3 & -4.1 & -3.3 \\
ECOSYS & -2.3 & -1.6 & -0.7 \\
ED2 & -2.1 & -2.4 & -3.4 \\
ISAM & -4.8 & -0.9 & -1.3 \\
ISOLSM & -4.7 & -0.8 & -1.4 \\
LOTEC & -4.7 & -2.2 & -4.4 \\
ORCHIDEE & -2.3 & -3.9 & -4.5 \\
SIB & -3.6 & -2.8 & -2.3 \\
SIBCASA & -4.5 & -2.9 & -3.6 \\
SSIB2 & -4.7 & -3.1 & -4.1 \\
TECO & -4.1 & -3.3 & -1.8 \\
\hline Measurements & -0.5 & -0.4 & -0.5 \\
\hline
\end{tabular}

ing the main growth period (Bonan, 2008; Priestley and Taylor, 1972). The dryland wheat crops studied here draw water from depth such that surface soils are often dry (Vick et al., 2016), minimizing $E_{\text {soil }}$. Applying the flux-variance similarity method of Scanlon and Kustas (2010) to the wheat crop and allowing the algorithm to estimate water use efficiency suggests that $T$ / ET frequently exceeds 0.95 during daytime periods when the algorithm converges (Fig. 5a). Repeating this analysis for a winter wheat crop near Sun River, Montana, USA, using the flux-variance similarity algorithm of Skaggs et al. (2018) confirms this finding with an even higher proportion of $T$ / ET values $(20 \%)$ that exceed 0.95 when allowing the algorithm to estimate water use efficiency. $T$ / ET, however, exceeded 0.95 in less than $2 \%$ of measurements using the approach of Perez-Priego et al. (2018) in a Mediterranean savanna ecosystem (Fig. 6). These observations suggest that the notion that $T$ /ET approaches 1 is a good assumption in some ecosystems, perhaps in ecosystems with high LAI, with implications for flux partitioning by the methods that rely on this assumption.

\section{Research imperatives}

Few field experiments have sought to constrain ecosystem $E$ and $T$ estimates using multiple observations to quantify their response to environmental variability and to test the assump-
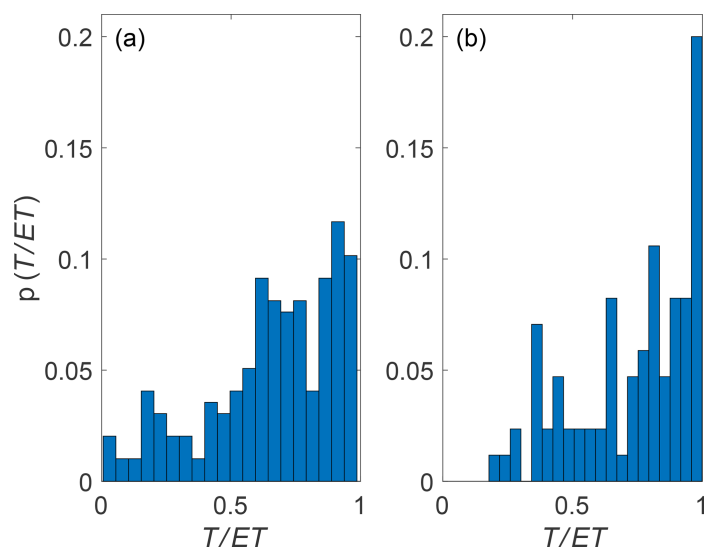

Figure 5. Distribution of the fraction of evapotranspiration arising during daytime hours from transpiration $(T)$ and evaporation $(E)$ estimated using the flux-variance similarity approach of Scanlon and Kustas (2010) from (a) a winter wheat field near Moore, MT, USA, described in Vick et al. (2016) using a version of the original algorithm. (b) A winter wheat field near Sun River, MT, using fluxpart (Skaggs et al., 2018).

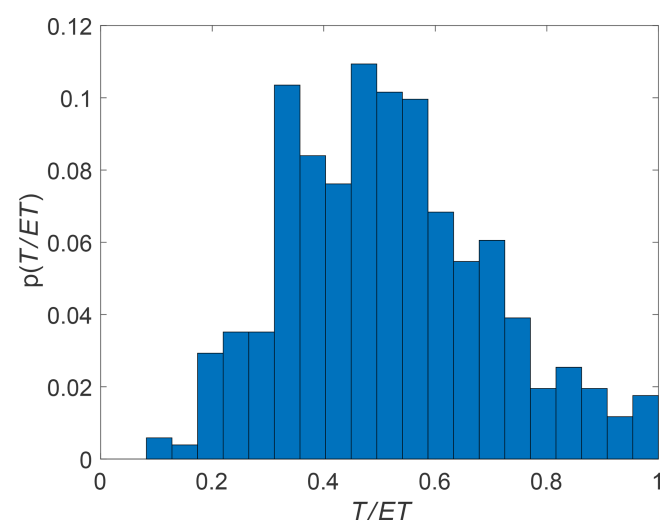

Figure 6. The distribution of the $T$ / ET ratio for half-hourly observations from the partitioning approach of Perez-Priego et al. (2018) for the Majadas de Tietar (ES-Lma), Spain, research site.

tions of partitioning approaches (Perez-Priego et al., 2017, 2018). Those that have note large discrepancies in $T$ / ET estimates from different techniques (Quade et al., 2019). Despite these challenges, a multi-measurement approach is necessary to understand different ecosystem water flux terms ( $\mathrm{Li}$ et al., 2018), but most multi-method ecosystem-scale experiments using eddy covariance measurements seek to constrain the carbon cycle rather than the water cycle to which it is coupled (Hanson et al., 2004; Williams et al., 2009). Here, we outline the basics of an ecosystem-scale experiment designed to address uncertainties in $E$ and $T$ measurements (Fig. 7).

It would be best to introduce such an experiment in an ecosystem with a relatively simple species distribution and a clear separation of above- and below-canopy $E$ and $T$ sources to apply flux-variance approaches (Klosterhalfen et 


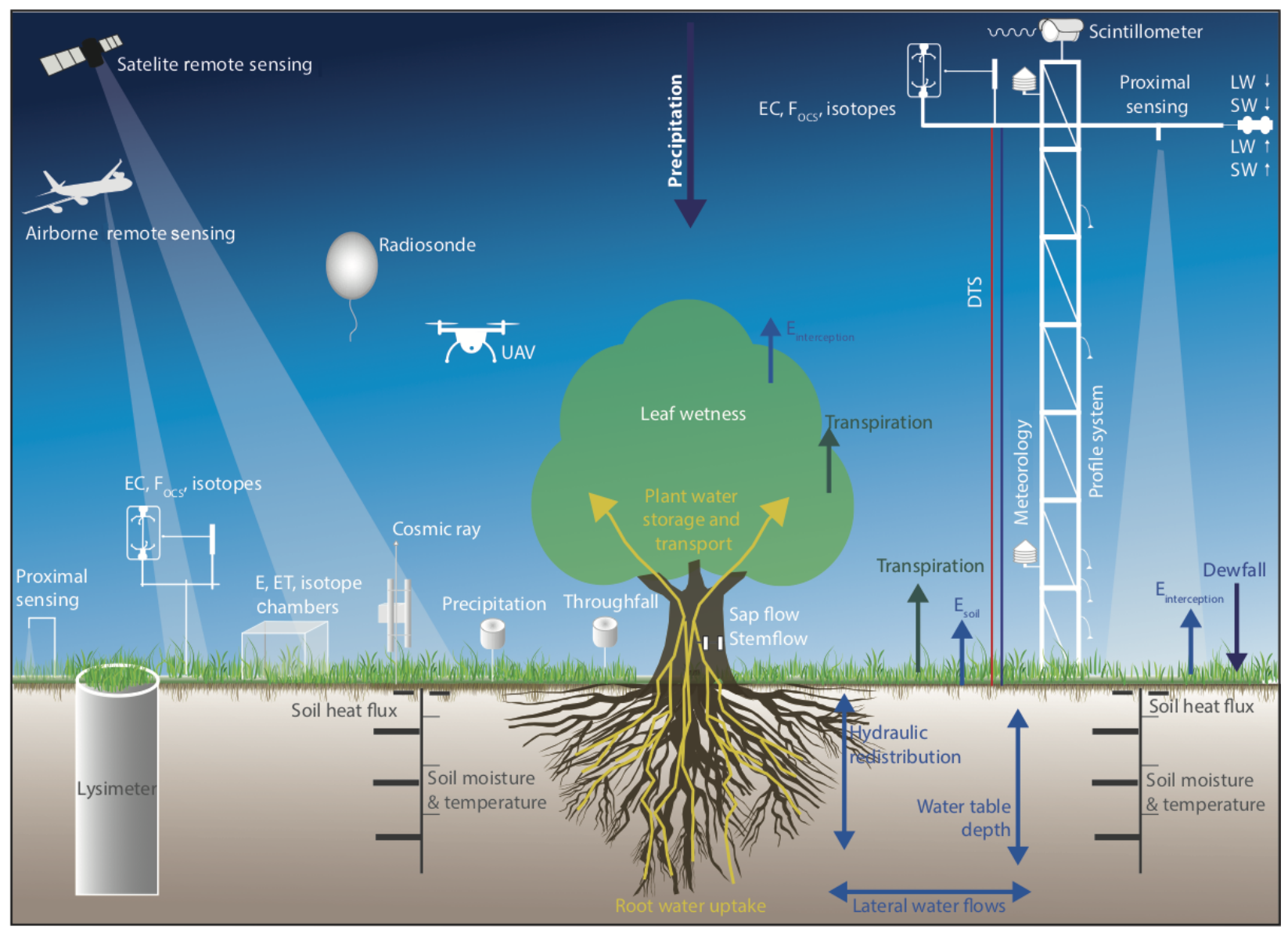

Figure 7. A schematic of an ecosystem experiment designed to measure transpiration and evaporation from soil and intercepted water using multiple complementary measurement approaches.

al., 2019b; Williams et al., 2004) before addressing more complex ecosystems with multiple canopy layers (Fu et al., 2018; Santos et al., 2016). Observations should occur on timescales commensurate with satellite remote sensing overpasses (see Appendix A); the half-hourly time step used in most eddy covariance observations is likely sufficient to approximate conditions captured by polar-orbiting satellites. For example, MODIS has a morning local overpass time for TERRA and afternoon overpass for AQUA; GOME2 makes SIF observations in the morning, and OCO-2 flies over in the early afternoon. There will be more opportunities to study diurnal patterns in $E$ and $T$ with the forthcoming and ongoing OCO-3, ECOSTRESS, and Geostationary Carbon Cycle Observatory (GeoCarb) missions. There are also underexplored opportunities to study ET partitioning using geostationary satellites like GOES (Bradley et al., 2010), which compromises a temporal resolution on the order of minutes with a spatial resolution from the distant geostationary orbit on the order of kilometers. These length scales may be wellcaptured by scintillometry, and ET partitioning approaches that employ scintillometry are largely lacking to date. A short measurement time step to align with satellite overpasses is possible for chambers, lysimeters, and sapflux measurements but not some isotopic approaches (Fig. 7). Critically, thermography, SIF, and COS flux can also be measured at these timescales. An ideal $E$ and $T$ partitioning experiment would make them both above and below plant canopies, in conjunction with below-canopy eddy covariance, to isolate $E_{\text {soil }}$ (Fig. 7). For full water balance accounting, observations of drainage from the rooting zone using drainage lysimeters, soil moisture at multiple soil levels spanning the root zone, the flow of water down plant stems (stemflow), leaf wetness sensors, measurements of the amount of water held in plants themselves, and of course multiple precipitation gauges are required. Such a multi-measurement approach would also create an opportunity to compare the performance of emerging technologies like distributed temperature sensing from fiber-optic cables (Schilperoort et al., 2018), modeling cosmic ray neutron fields for soil water source estimation (Andreasen et al., 2016), and global navigation satellite system reflectometry (GNSS-R) for soil moisture estimation (Zribi et al., 2018). It remains difficult to assimilate $E$ and $T$ measurements into models using conventional data assimilation techniques because observations may contain substantial bias 
error yet still provide valuable information (Williams et al., 2009). Emerging approaches from machine learning in the Earth and environmental sciences may therefore be particularly useful for combining the best information from different measurement techniques into a mass- and energy-conserving model of the surface-atmosphere exchange of water (Reichstein et al., 2019). Regardless of the specifics of the multimeasurement approach for constraining $E$ and $T$ measurements, we advocate more investment into the study of ET, "green water", given its central importance in provisioning resources to an increasingly resource-scarce planet (Schyns et al., 2019).

\section{Conclusion}

New measurement techniques and analytical approaches for partitioning $E$ and $T$ at the ecosystem scale provide critical opportunities to improve land surface models, remote sensing products, and ultimately our understanding of the global water cycle. Ecosystem-scale experiments that measure $E$ and $T$ using multiple approaches are needed to understand how $E$ and $T$ respond differently to climate variability and change across different global ecosystems and also to critique the assumptions made by ET partitioning approaches to improve their skill. By strengthening our focus on the water cycle in studies of coupled carbon and water fluxes, our understanding of the role of the land surface in the climate system can only improve.
Data availability. The terrestrial biosphere model and aggregated flux data can be found in Ricciuto et al. (2013; https://doi.org/10.3334/ORNLDAAC/1183). Data from the winter wheat field near Moore, MT, are available as Ameriflux site US$\mathrm{Mj} 1$ at https://ameriflux.lbl.gov/sites/siteinfo/US-Mj1 (last access: 29 September 2019). Data from the winter wheat field near Sun River, MT, will be submitted to Ameriflux with the site name USMsr. 


\section{Appendix A}

For completeness we briefly describe common algorithms used by remote sensing platforms for estimating $E, T$, and ET, noting that additional approaches exist and are under development (El Masri et al., 2019). Many widely used algorithms including SEBAL (Bastiaanssen et al., 1998), METRIC (Allen et al., 2007; Su, 2002), and SEBS (Su, 2002) use an energy balance approach that does not explicitly seek to separate $T$ from $E$ but remain highly valuable for water resource management and hydrology.

\section{A1 PT-JPL}

The Priestley-Taylor Jet Propulsion Lab (PT-JPL) global ET remote sensing retrieval algorithm (Fisher et al., 2008) is based on the potential evapotranspiration (PET) formulation of Priestley and Taylor (1972), which replaces the adiabatic terms in Eq. (1) with a parameter, $\alpha_{\mathrm{PT}}$, that takes a value of 1.26 under ideal evaporating conditions:

$\mathrm{PET}=\alpha_{\mathrm{PT}} \frac{s\left(R_{\mathrm{n}}-G\right)}{s+\gamma}$.

To reduce PET to ET, Fisher et al. (2008) introduced ecophysiological constraint functions ( $f$ functions, unitless multipliers between 0 and 1) following Jarvis (1976). These are based on $D$, relative humidity (RH), the normalized difference vegetation index (NDVI), and the soil-adjusted vegetation index (SAVI; Huete, 1988). PT-JPL calculates $T, E_{\text {soil }}$, and $E_{\mathrm{i}}$ explicitly using

$\mathrm{ET}=T+E_{\mathrm{soil}}+E_{\mathrm{i}}$,

$T=\left(1-f_{\text {wet }}\right) f_{\mathrm{g}} f_{\mathrm{Temp}} f_{\mathrm{M}} \alpha_{\mathrm{PT}} \frac{s\left(R_{\mathrm{nc}}-G\right)}{s+\gamma}$,

$E_{\mathrm{soil}}=\left(f_{\mathrm{wet}}+f_{\mathrm{SM}}\left(1-f_{\mathrm{wet}}\right)\right) \alpha_{\mathrm{PT}} \frac{s\left(R_{\mathrm{ns}}-G\right)}{s+\gamma}$,

$E_{\mathrm{i}}=f_{\mathrm{wet}} \alpha_{\mathrm{PT}} \frac{s\left(R_{\mathrm{nc}}-G\right)}{s+\gamma}$,

where $f_{\text {wet }}$ is relative surface wetness $\left(\mathrm{RH}^{4}\right), f_{\mathrm{g}}$ is green canopy fraction, $f_{\text {Temp }}$ is a plant temperature constraint, $f_{\mathrm{M}}$ is a plant moisture constraint, and $f_{\mathrm{SM}}$ is a soil moisture constraint. $R_{\mathrm{nc}}$ and $R_{\mathrm{ns}}$ are net radiation absorbed by the canopy and soil, respectively. PT-JPL has been tested against measured ET from hundreds of FLUXNET sites worldwide, with a monthly average $r^{2}$ of 0.90 across all sites and a slope / bias of 1.07 using in situ data (Fisher et al., 2008, 2009). The PT-JPL model forms the core ET retrieval algorithm in the ECOSTRESS mission (Fisher et al., 2017; Hulley et al., 2017) onboard the International Space Station. New applications of the PT-JPL algorithm have included canopy indices derived from CubeSats (Aragon et al., 2018).

\section{A2 PM-MOD16}

The PM-MOD16 algorithm estimates ET at 8-day intervals at $1 \mathrm{~km}^{2}$ pixels across the global terrestrial surface with MODIS observations following Mu et al. (2011) using Eq. (A2). The PM-MOD16 algorithm follows the PenmanMonteith model (Eq. 1) rather than the Priestley-Taylor model (Eq. A1) by modeling conductance terms (or resistance terms as the inverse of the conductance terms in Eq. 1) rather than including $f$ functions as in the PT-JPL algorithm. It explains ca. $86 \%$ of the variability in eddy-covarianceobserved ET from 46 sites in North America (Mu et al., 2011).

\section{A3 GLEAM}

The Global Land Evaporation Amsterdam Model (GLEAM) (Miralles et al., 2011a, b) also uses a Priestley-Taylor approach (Eq. A1) to estimate ET. It employs the Gash (1979) analytical model for canopy rainfall interception and semiempirical stress functions that vary between 0 and 1 (similar to the $f$ functions of the PT-JPL model) to reduce PET to $T$ for canopies with different characteristics. For $T$, this stress function is calculated based on the content of water in vegetation and the root zone. The former is approximated based on microwave vegetation optical depth and the latter is calculated using a multilayer soil model driven by observations of precipitation and updated through the assimilation of microwave surface soil moisture. Validation studies against eddy covariance data at daily timescales show average correlations typically ranging $0.81-0.86$ (Martens et al., 2017).

\section{A4 DTD}

The dual-temperature difference (DTD) model follows the notion that diurnal changes in air and radiometric surface temperatures are related to surface-atmosphere heat flux (Norman et al., 2000). It has since been applied to MODIS observations to estimate ET (Guzinski et al., 2013) and to partition $E$ and $T$ using a Priestly-Taylor scheme described in Song et al. (2018). DTD estimates of $E$ and $T$ compared well to estimates derived using the flux-variance similarity algorithm of Skaggs et al. (2018).

\section{A5 ALEXI-DisALEXI}

Atmosphere-Land Exchange Inverse (ALEXI) is a multiscale surface energy balance modeling system building on the two-source energy balance (TSEB) land surface representation of Norman et al. (1995). The TSEB partitions the composite radiometric surface temperature, Temprad, into soil and canopy temperatures, Temp $\mathrm{s}_{\mathrm{s}}$ and $\mathrm{Temp}_{\mathrm{c}}$, based on the local vegetation cover fraction apparent at the thermal sensor 
view angle, $f(\theta)$ :

Temp $_{\mathrm{rad}} \cong f(\theta)$ Temp $_{\mathrm{c}}+(1-f(\theta)) \mathrm{Temp}_{\mathrm{s}}$.

With information about Temprad, LAI, and radiative forcing, the TSEB evaluates the soil (subscript "s") and canopy ("c") energy budgets separately by computing system and component fluxes of $R_{\mathrm{n}}, H$, and ET (i.e., ET from soil and canopy), as well as $G$. Because angular effects are incorporated in Eq. (A6), the TSEB can accommodate thermal data acquired at off-nadir viewing angles by geostationary satellites. The TSEB has a built-in mechanism for detecting thermal signatures of stress in the soil and canopy. An initial iteration assumes that $T$ is occurring at a potential (nonmoisture-limited) rate, while $E_{\text {soil }}$ is computed as a residual to the system energy budget. If the vegetation is stressed and transpiring at significantly less than the potential rate, $T$ will be overestimated and the residual $E_{\text {soil }}$ will become negative. Condensation onto the soil is unlikely midday on clear days, and therefore $E_{\text {soil }}<0$ is considered a signature of system stress. Under such circumstances, $T$ is iteratively down-regulated until $E_{\text {soil }}=0$, noting that this assumption has been challenged by recent observations in some ecosystems (Perez-Priego et al., 2018).
For regional-scale applications of the TSEB, air temperature boundary conditions are difficult to specify with adequate accuracy due to localized land-atmosphere feedback. To overcome this limitation, the TSEB has been coupled with an atmospheric boundary layer (ABL) model, thereby simulating land-atmosphere feedback internally. In ALEXI (Anderson, 1997; Anderson et al., 2007), the TSEB is applied at two times during the morning $\mathrm{ABL}$ growth phase (between sunrise and local noon) using thermal infrared observations from geostationary satellites. Energy closure over this interval is provided by a simple slab ABL model (McNaughton and Spriggs, 1986), which relates the rise in air temperature in the mixed layer to the time-integrated influx of $H$ from the land surface. As a result, ALEXI uses only time-differential temperature signals, thereby minimizing flux errors due to absolute sensor calibration and atmospheric and emissivity corrections (Kustas et al., 2001). For local-scale applications on length scales similar to many flux footprints on the order of $100 \mathrm{~m}$, the coarse-scale flux estimates can be spatially disaggregated using the DisALEXI technique (Norman et al., 2003). DisALEXI uses air temperature diagnosed by ALEXI at a nominal blending height along with high-resolution LAI and land surface temperature data from polar-orbiting satellites to estimate fluxes at finer scales. 
Author contributions. PCS, TSEM, JBF, TG, OPP, and THS performed the analyses used to create figures, and PCS performed the analyses used to create Table 2. PCS, JBF, PG, TG, SPG, AK, SL, DGM, AJR, and GW were responsible for writing subsections of the paper, and all authors contributed to writing the text.

Competing interests. The authors declare that they have no conflict of interest.

Acknowledgements. Gabriel Bromley, Adam Cook, Elizabeth Vick, and Skylar Williams assisted with data collection and analysis, Chuck Merja, Scott Powell, James Irvine, and Bruce Maxwell provided logistical support, and Elke Eichelmann provided valuable comments on earlier drafts of this paper. We also acknowledge financial support for the eddy covariance data harmonization provided by CarboEuropeIP, FAO-GTOS-TCO, iLEAPS, the Max Planck Institute for Biogeochemistry, the National Science Foundation, the University of Tuscia, Universite' Laval, Environment Canada, the US Department of Energy, database development and technical support from the Berkeley Water Center, the Lawrence Berkeley National Laboratory, Microsoft Research eScience, Oak Ridge National Laboratory, the University of California - Berkeley, and the University of Virginia. We would additionally like to thank the North American Carbon Program Site-Level Interim Synthesis team, the Modeling and Synthesis Thematic Data Center, the Oak Ridge National Laboratory Distributed Active Archive Center, and Larry Flanagan for collecting, organizing, and distributing the model output used in this analysis. The authors want to thank Silvana Schott for her support in producing Fig. 7.

Financial support. Paul C. Stoy acknowledges support from the Alexander von Humboldt Foundation, the U.S. National Science Foundation award numbers 1552976, 1241881, and 1702029, the Montana Wheat and Barley Committee, and the USDA National Institute of Food and Agriculture Hatch project 228396 and Multi-State project W3188. Diego G. Miralles and Wouter H. Maes acknowledge support from the European Research Council (ERC) under grant agreement 715254 (DRY-2-DRY) and the Belgian Science Policy Office (BELSPO) in the framework of the STEREO III program project STR3S (SR/02/329). Ivan Mammarella acknowledges the Academy of Finland Center of Excellence (project nos. 272041 and 118780) and ICOS-Finland (project no. 281255). Tarek S. El-Madany, Mirco Migliavacca, and Oscar Perez-Priego thank the Alexander von Humboldt Foundation for financial support through the Max Planck Research Prize to Markus Reichstein. A. Miriam J. Coenders-Gerrits acknowledges NWO Earth and Life Sciences (ALW), veni-project 863.15.022, the Netherlands. Mirco Migliavacca acknowledges the support of the Training on Remote Sensing for Ecosystem Modelling (Trustee) European Commission project no. H2020-MSCA-ITN2016-721995. Todd H. Skaggs and Ray G. Anderson acknowledge the USDA-ARS Office of National Programs (project number 2036-61000-018-00-D). Joshua B. Fisher contributed to this research at the Jet Propulsion Laboratory, California Institute of Technology, under a contract with the National Aeronautics and Space Administration. California Institute of Technology government sponsorship is acknowledged. Joshua B. Fisher was supported in part by the NASA programs SUSMAP, WWAO, INCA, IDS, and ECOSTRESS. Georg Wohlfahrt acknowledges financial support from the Austrian National Science Fund (FWF; grant nos. P27176 and I3859). Rafael Poyatos was supported by the Spanish MINECO-MICINN grant CGL2014-55583-JIN.

The article processing charges for this open-access publication were covered by the Max Planck Society.

Review statement. This paper was edited by Martin De Kauwe and reviewed by Zhongwang Wei and three anonymous referees.

\section{References}

Abtew, W. and Assefa M.: Evaporation and evapotranspiration: measurements and estimations, Springer Science \& Business Media, Berlin, 2012.

Alemohammad, S. H., Fang, B., Konings, A. G., Aires, F., Green, J. K., Kolassa, J., Miralles, D., Prigent, C., and Gentine, P.: Water, Energy, and Carbon with Artificial Neural Networks (WECANN): a statistically based estimate of global surface turbulent fluxes and gross primary productivity using solar-induced fluorescence, Biogeosciences, 14, 4101-4124, https://doi.org/10.5194/bg-14-4101-2017, 2017.

Allen, R. G., Tasumi, M., and Trezza, R.: Satellite-based energy balance for mapping evapotranspiration with internalized calibration (METRIC) - Model, J. Irrig. Drain. Eng., 133, 380-394, 2007.

Allison, G. B. and Barnes, C. J.: Estimation of evaporation from non-vegetated surfaces using natural deuterium, Nature, 301, 143-145, 1983.

Anderson, M.: A two-source time-integrated model for estimating surface fluxes using thermal infrared remote sensing, Remote Sens. Environ., 60, 195-216, 1997.

Anderson, M. C., Norman, J. M., Mecikalski, J. R., Otkin, J. A., and Kustas, W. P.: A climatological study of evapotranspiration and moisture stress across the continental United States based on thermal remote sensing: 1. Model formulation, J. Geophys. Res.Atmos., 112, D10117, https://doi.org/10.1029/2006jd007506, 2007.

Anderson, M. C., Allen, R. G., Morse, A., and Kustas, W. P.: Use of Landsat thermal imagery in monitoring evapotranspiration and managing water resources, Remote Sens. Environ., 122, 50-65, 2012.

Anderson, R. G., Alfieri, J. G., Tirado-Corbalá, R., Gartung, J., McKee, L. G., Prueger, J. H., Wang, D., Ayars, J. E., and Kustas, W. P.: Assessing FAO-56 dual crop coefficients using eddy covariance flux partitioning, Agr. Water Manage., 179, 92-102, 2017a.

Anderson, R. G., Zhang, X., and Skaggs, T. H.: Measurement and partitioning of evapotranspiration for application to vadose zone studies, Vadose Zone J., 16, https://doi.org/10.2136/vzj2017.08.0155, 2017b.

Andreasen, M., Jensen, K. H., Zreda, M., Desilets, D., Bogena, H., and Looms, M. C.: Modeling cosmic ray neutron field measurements, Water Resour. Res., 52, 6451-6471, 2016. 
Aragon, B., Houborg, R., Tu, K., Fisher, J. B., and McCabe, M.: CubeSats enable high spatiotemporal retrievals of cropwater use for precision agriculture, Remote Sens., 10, 1867, https://doi.org/10.3390/rs10121867, 2018.

Arain, M. A., Altaf Arain, M., Yuan, F., and Andrew Black, T.: Soilplant nitrogen cycling modulated carbon exchanges in a western temperate conifer forest in Canada, Agr. Forest Meteorol., 140, 171-192, 2006.

Asaf, D., Rotenberg, E., Tatarinov, F., Dicken, U., Montzka, S. A., and Yakir, D.: Ecosystem photosynthesis inferred from measurements of carbonyl sulphide flux, Nat. Geosci., 6, 186-190, https://doi.org/10.1038/ngeo1730, 2013.

Aubrecht, D. M., Helliker, B. R., Goulden, M. L., Roberts, D. A., Still, C. J., and Richardson, A. D.: Continuous, long-term, highfrequency thermal imaging of vegetation: Uncertainties and recommended best practices, Agr. Forest Meteorol., 228-229, 315326, 2016.

Badgley, G., Fisher, J. B., Jiménez, C., Tu, K. P., and Vinukollu, R.: On uncertainty in global terrestrial evapotranspiration estimates from choice of input forcing datasets, J. Hydrometeorol., 16, 1449-1455, 2015.

Baker, I. T., Prihodko, L., Denning, A. S., Goulden, M., Miller, S., and da Rocha, H. R.: Seasonal drought stress in the Amazon: Reconciling models and observations, J. Geophys Res.-Biogeo., 113, G00B01, https://doi.org/10.1029/2007jg000644, 2008.

Baldocchi, D. D. and Ryu, Y.: A synthesis of forest evaporation fluxes - from days to years - as measured with eddy covariance, in: Ecological Studies, edited by: Levia, D. F., Carlyle-Moses, D., and Tanaka, T., Springer, Berlin, 101-116, 2011.

Baldocchi, D. D., Vogel, C. A., and Hall, B.: Seasonal variation of energy and water vapor exchange rates above and below a boreal jack pine forest canopy, J. Geophys. Res.-Atmos., 102, 2893928951, 1997.

Bastiaanssen, W. G. M., Menenti, M., Feddes, R. A., and Holtslag, A. A. M.: A remote sensing surface energy balance algorithm for land (SEBAL). 1. Formulation, J. Hydrol., 212-213, 198-212, 1998.

Berkelhammer, M., Noone, D. C., Wong, T. E., Burns, S. P., Knowles, J. F., Kaushik, A., Blanken, P. D., and Williams, M. W.: Convergent approaches to determine an ecosystem's transpiration fraction, Global Biogeochem. Cy., 30, 933-951, 2016.

Black, T. A., Gardner, W. R., and Thurtell, G. W.: The prediction of evaporation, drainage, and soil water storage for a bare soil, Soil Sci. Soc. Am. J., 33, 655-660, 1969.

Blyth, E. and Harding, R. J.: Methods to separate observed global evapotranspiration into the interception, transpiration and soil surface evaporation components, Hydrol. Process., 25, 4063 4068, 2011.

Boese, S., Jung, M., Carvalhais, N., and Reichstein, M.: The importance of radiation for semiempirical water-use efficiency models, Biogeosciences, 14, 3015-3026, https://doi.org/10.5194/bg-143015-2017, 2017.

Boese, S., Jung, M., Carvalhais, N., Teuling, A. J., and Reichstein, M.: Carbon-water flux coupling under progressive drought, Biogeosciences, 16, 2557-2572, https://doi.org/10.5194/bg-162557-2019, 2019.

Bohrer, G., Mourad, H., Laursen, T. A., Drewry, D., Avissar, R., Poggi, D., Oren, R., and Katul, G. G.: Finite element tree crown hydrodynamics model (FETCH) using porous media flow within branching elements: A new representation of tree hydrodynamics, Water Resour. Res., 41, W11404, https://doi.org/10.1029/2005wr004181, 2005.

Bonan, G. B.: Forests and climate change: forcings, feedbacks, and the climate benefits of forests, Science, 320, 1444-1449, 2008.

Botev, Z. I., Grotowski, J. F., and Kroese, D. P.: Kernel density estimation via diffusion, Ann. Stat., 38, 2916-2957, 2010.

Bouchet, R. J. Evapotranspiration potentielle et évaporation sous abri, Biometeorology, Pergamon, 540-545, 1962.

Boulet, G., Chehbouni, A., Braud, I., and Vauclin, M.: Mosaic versus dual source approaches for modelling the surface energy balance of a semi-arid land, Hydrol. Earth Syst. Sci., 3, 247-258, https://doi.org/10.5194/hess-3-247-1999, 1999.

Bowen, G. J. and Good, S. P.: Incorporating water isoscapes in hydrological and water resource investigations, Wiley Interdisciplinary Reviews: Water, 2, 107-119, 2015.

Braden-Behrens, J., Markwitz, C., and Knohl, A.: Eddy covariance measurements of the dual-isotope composition of evapotranspiration, Agr. Forest Meteorol., 269-270, 203-219, 2019.

Bradley, E. S., Toomey, M. P., Still, C. J., and Roberts, D. A.: Multiscale sensor fusion with an online application: Integrating GOES, MODIS, and webcam imagery for environmental monitoring, IEEE J. Sel. Top. Appl., 3, 497-506, 2010.

Braud, I., Bariac, T., Vauclin, M., Boujamlaoui, Z., Gaudet, J. P., Biron, P., and Richard, P.: SiSPAT-Isotope, a coupled heat, water and stable isotope ( $\mathrm{HDO}$ and $\mathrm{H}_{2}^{18} \mathrm{O}$ ) transport model for bare soil. Part II. Evaluation and sensitivity tests using two laboratory data sets, J. Hydrol., 309, 301-320, 2005.

Brutsaert, W.: Use of pan evaporation to estimate terrestrial evaporation trends: The case of the Tibetan Plateau, Water Resour. Res., 49, 3054-3058, 2013.

Brutsaert, W.: Daily evaporation from drying soil: Universal parameterization with similarity, Water Resour. Res., 50, 3206-3215, 2014.

Brutsaert, W.: Global land surface evaporation trend during the past half century: Corroboration by Clausius-Clapeyron scaling, Adv. Water Resour., 106, 3-5, 2017.

Brutsaert, W. and Parlange, M. B.: Hydrologic cycle explains the evaporation paradox, Nature, 396, 30-30, 1998.

Bunce, J. A.: Nonstomatal inhibition of photosynthesis by water stress. Reduction in photosynthesis at high transpiration rate without stomatal closure in field-grown tomato, Photosynth. Res., 18, 357-362, 1988.

Cammalleri, C., Agnese, C., Ciraolo, G., Minacapilli, M., Provenzano, G., and Rallo, G.: Actual evapotranspiration assessment by means of a coupled energy/hydrologic balance model: Validation over an olive grove by means of scintillometry and measurements of soil water contents, J. Hydrol., 392, 70-82, 2010.

Campbell, G. S. and Norman, J. M.: An Introduction to Environmental Biophysics, 1998.

Campbell, J. E., Carmichael, G. R., Chai, T., Mena-Carrasco, M., Tang, Y., Blake, D. R., Blake, N. J., Vay, S. A., Collatz, G. J., Baker, I., Berry, J. A., Montzka, S. A., Sweeney, C., Schnoor, J. L., and Stanier, C. O.: Photosynthetic control of atmospheric carbonyl sulfide during the growing season, Science, 322, 10851088, 2008.

Cernusak, L. A., Ubierna, N., Jenkins, M. W., Garrity, S. R., Rahn, T., Powers, H. H., Hanson, D. T., Sevanto, S., Wong, S. C., McDowell, N. G., and Farquhar, G. D.: Unsaturation of vapour pres- 
sure inside leaves of two conifer species, Sci. Rep.-UK, 8, 7667, https://doi.org/10.1038/s41598-018-25838-2, 2018.

Chang, L.-L., Dwivedi, R., Knowles, J. F., Fang, Y.-H., Niu, G.-Y., Pelletier, J. D., Rasmussen, C., Durcik, M., Barron-Gafford, G. A., and Meixner, T.: Why do land surface models produce a low ratio of transpiration to evapotranspiration?, J. Geophys. Res.Atmos., 123, 9109-9130, 2018.

Chu, H., Baldocchi, D. D., John, R., Wolf, S., and Reichstein, M.: Fluxes all of the time? A primer on the temporal representativeness of FLUXNET, J. Geophys. Res.-Biogeo., 122, 289-307, 2017.

Cisneros Vaca, C., van der Tol, C., and Ghimire, C. P.: The influence of long-term changes in canopy structure on rainfall interception loss: a case study in Speulderbos, the Netherlands, Hydrol. Earth Syst. Sci., 22, 3701-3719, https://doi.org/10.5194/hess-22-37012018, 2018.

Coenders-Gerrits, A. M. J., van der Ent, R. J., Bogaard, T. A., WangErlandsson, L., Hrachowitz, M., and Savenije, H. H. G.: Uncertainties in transpiration estimates, Nature, 506, E1-2, 2014.

Craig, H. and Gordon, L. I.: Deuterium and Oxygen 18 Variations in the Ocean and the Marine Atmosphere, Stable Isotopes in Oceanic Studies and Paleotemperatures, 9-130, 1965.

Crockford, R. H. and Richardson, D. P.: Partitioning of rainfall into throughfall, stemflow and interception: effect of forest type, ground cover and climate, Hydrol. Process., 14, 2903-2920, 2000.

Damm, A., Roethlin, S., and Fritsche, L.: Towards advanced retrievals of plant transpiration using sun-induced chlorophyll fluorescence: First considerations, in IGARSS 2018 - 2018 IEEE International Geoscience and Remote Sensing Symposium, Valencia, Spain, 2018.

De Kauwe, M. G., Medlyn, B. E., Zaehle, S., Walker, A. P., Dietze M. C., Hickler, T., Jain, A. K., Luo, Y., Parton, W. J., Prentice, I., C., Smith, B., Thornton, P. E., Wang, S., Wang, Y.-P., Wårlind D., Weng, E., Crous, K., Y., Ellsworth, D. S., Hanson, P. J., Kim, H.-S., Warren, J. M., Oren, R., and Norby, R. J.: Forest water use and water use efficiency at elevated $\mathrm{CO}_{2}$ : a model-data intercomparison at two contrasting temperate forest FACE sites, Glob. Change Biol., 19, 1759-1779, 2013.

De Kauwe, M. G., Medlyn, B. E., Knauer, J., and Williams, C. A.: Ideas and perspectives: how coupled is the vegetation to the boundary layer?, Biogeosciences, 14, 4435-4453, https://doi.org/10.5194/bg-14-4435-2017, 2017.

De Kauwe, M. G., Medlyn, B. E., Pitman, A. J., Drake, J. E., Ukkola, A., Griebel, A., Pendall, E., Prober, S., and Roderick, M.: Examining the evidence for decoupling between photosynthesis and transpiration during heat extremes, Biogeosciences, 16, 903-916, https://doi.org/10.5194/bg-16-903-2019, 2019.

Dolman, A. J., Miralles, D. G., and de Jeu, R. A. M.: Fifty years since Monteith's 1965 seminal paper: the emergence of global ecohydrology, Ecohydrol., 7, 897-902, 2014.

Ellsworth, D. S., Oren, R., Huang, C., Phillips, N., and Hendrey, G. R.: Leaf and canopy responses to elevated $\mathrm{CO}_{2}$ in a pine forest under free-air $\mathrm{CO}_{2}$ enrichment, Oecologia, 106, 416-416, 1996.

El Masri, B., Rahman, A. F., and Dragoni, D.: Evaluating a new algorithm for satellite-based evapotranspiration for North American ecosystems: Model development and validation, Agr. Forest Meteorol., 268, 234-248, 2019.
Fang, Y., Leung, L. R., Duan, Z., Wigmosta, M. S., Maxwell, R. M., Chambers, J. Q., and Tomasella, J.: Influence of landscape heterogeneity on water available to tropical forests in an Amazonian catchment and implications for modeling drought response, J. Geophys. Res.-Atmos., 122, 8410-8426, 2017.

Farquhar, G. D. and Cernusak, L. A.: On the isotopic composition of leaf water in the non-steady state, Funct. Plant Biol., 32, 293 303, https://doi.org/10.1071/FP04232, 2005.

Fatichi, S. and Pappas, C.: Constrained variability of modeled T:ET ratio across biomes, Geophys. Res. Lett., 44, 6795-6803, 2017.

Ficklin, D. L. and Novick, K. A.: Historic and projected changes in vapor pressure deficit suggest a continental-scale drying of the United States atmosphere, J. Geophys. Res.-Atmos., 122, 20612079, 2017.

Field, C. B., Jackson, R. B., and Mooney, H. A.: Stomatal responses to increased $\mathrm{CO}_{2}$ : implications from the plant to the global scale, Plant Cell Environ., 18, 1214-1225, 1995.

Fisher, J. B., Tu, K. P., and Baldocchi, D. D.: Global estimates of the land-atmosphere water flux based on monthly AVHRR and ISLSCP-II data, validated at 16 FLUXNET sites, Remote Sens. Environ., 112, 901-919, 2008.

Fisher, J. B., Malhi, Y., Bonal, D., da Rocha, H. R., de Araãšjo, A. C., Gamo, M., Goulden, M. L., Hirano, T., Huete, A. R., Kondo, H., Kumagai, T., Loescher, H. W., Miller, S., Nobre, A. D., Nouvellon, Y., Oberbauer, S. F., Panuthai, S., Roupsard, O., Saleska, S., Tanaka, K., Tanaka, N., Tu, K. P., and Von Randow, C.: The land-atmosphere water flux in the tropics, Glob. Change Biol., 15, 2694-2714, 2009.

Fisher, J. B., Whittaker, R. J., and Malhi, Y.: ET come home: potential evapotranspiration in geographical ecology, Global Ecol. Biogeogr., 20, 1-18, 2010.

Fisher, J. B., Melton, F., Middleton, E., Hain, C., Anderson, M., Allen, R., McCabe, M. F., Hook, S., Baldocchi, D., Townsend, P. A., Kilic, A., Tu, K., Miralles, D. D., Perret, J., Lagouarde, J.-P., Waliser, D., Purdy, A. J., French, A., Schimel, D., Famiglietti, J. S., Stephens, G., and Wood, E. F.: The future of evapotranspiration: Global requirements for ecosystem functioning, carbon and climate feedbacks, agricultural management, and water resources, Water Resour. Res., 53, 2618-2626, 2017.

Flanagan, L. B. and Ehleringer, J. R.: Stable isotope composition of stem and leaf water: Applications to the study of plant water use, Funct. Ecol., 5, 270-277, https://doi.org/10.2307/2389264, 1991.

Frankenberg, C., Fisher, J. B., Worden, J., Badgley, G., Saatchi, S. S., Lee, J.-E., Toon, G. C., Butz, A., Jung, M., Kuze, A., and Yokota, T.: New global observations of the terrestrial carbon cycle from GOSAT: Patterns of plant fluorescence with gross primary productivity, Geophys. Res. Lett., 38, L17706, https://doi.org/10.1029/2011gl048738, 2011.

Fratini, G., Ibrom, A., Arriga, N., Burba, G., and Papale, D.: Relative humidity effects on water vapour fluxes measured with closed-path eddy-covariance systems with short sampling lines, Agr. Forest Meteorol., 165, 53-63, 2012.

Fu, Z., Gerken, T., Bromley, G., Araújo, A., Bonal, D., Burban, B., Ficklin, D., Fuentes, J. D., Goulden, M., Hirano, T., Kosugi, Y., Liddell, M., Nicolini, G., Niu, S., Roupsard, O., Stefani, P., Mi, C., Tofte, Z., Xiao, J., Valentini, R., Wolf, S., and Stoy, P. C.: The surface-atmosphere exchange of carbon dioxide in tropical rain- 
forests: Sensitivity to environmental drivers and flux measurement methodology, Agr. Forest Meteorol., 263, 292-307, 2018.

Gaj, M., Beyer, M., Koeniger, P., Wanke, H., Hamutoko, J., and Himmelsbach, T.: In situ unsaturated zone water stable isotope $\left({ }^{2} \mathrm{H}\right.$ and $\left.{ }^{18} \mathrm{O}\right)$ measurements in semi-arid environments: a soil water balance, Hydrol. Earth Syst. Sci., 20, 715-731, https://doi.org/10.5194/hess-20-715-2016, 2016.

Gash, J.: An analytical model of rainfall interception by forests, Q. J. Roy. Meteor. Soc., 105, 43-55, 1979.

Gat, J. R.: Oxygen and hydrogen isotopes in the hydrologic cycle, Annu. Rev. Earth Planet. Sc., 24, 225-262, 1996.

Gedney, N., Cox, P. M., Betts, R. A., Boucher, O., Huntingford, C., and Stott, P. A.: Detection of a direct carbon dioxide effect in continental river runoff records, Nature, 439, 835-838, 2006.

Gentine, P., Chhang, A., Rigden, A., and Salvucci, G.: Evaporation estimates using weather station data and boundary layer theory, Geophys. Res. Lett., 43, 11661-11670, 2016.

Gerdel, K., Spielmann, F. M., Hammerle, A., and Wohlfahrt, G.: Eddy covariance carbonyl sulfide flux measurements with a quantum cascade laser absorption spectrometer, Atmos. Meas. Tech., 10, 3525-3537, https://doi.org/10.5194/amt-103525-2017, 2017.

Gerken, T., Bromley, G. T., and Stoy, P. C.: Surface moistening trends in the northern North American Great Plains increase the likelihood of convective initiation, J. Hydrometeorol., 19, 227 244, 2018

Good, S. P., Soderberg, K., Guan, K., King, E. G., Scanlon, T. M., and Caylor, K. K.: $\delta^{2} \mathrm{H}$ isotopic flux partitioning of evapotranspiration over a grass field following a water pulse and subsequent dry down, Water Resour. Res., 50, 1410-1432, 2014.

Good, S. P., Noone, D., and Bowen, G.: Hydrologic connectivity constrains partitioning of global terrestrial water fluxes, Science, 349, 175-177, 2015.

Good, S. P., Moore, G. W., and Miralles, D. G.: A mesic maximum in biological water use demarcates biome sensitivity to aridity shifts, Nat. Ecol. Evol., 1, 1883-1888, 2017.

Grant, R. F., Arain, A., Arora, V., Barr, A., Black, T. A., Chen, J., Wang, S., Yuan, F., and Zhang, Y.: Intercomparison of techniques to model high temperature effects on $\mathrm{CO}_{2}$ and energy exchange in temperate and boreal coniferous forests, Ecol. Model., 188, 217-252, 2005.

Griffis, T. J., Black, T. A., Morgenstern, K., Barr, A. G., Nesic, Z., Drewitt, G. B., Gaumont-Guay, D., and McCaughey, J. H.: Ecophysiological controls on the carbon balances of three southern boreal forests, Agr. Forest Meteorol., 117, 53-71, 2003.

Griffis, T. J., Lee, X., Baker, J. M., Sargent, S. D., and King, J. Y.: Feasibility of quantifying ecosystem-atmosphere $\mathrm{C}^{18} \mathrm{O}^{16} \mathrm{O}$ exchange using laser spectroscopy and the flux-gradient method, Agr. Forest Meteorol., 135, 44-60, 2005.

Griffis, T. J., Sargent, S. D., Lee, X., Baker, J. M., Greene, J., Erickson, M., Zhang, X., Billmark, K., Schultz, N., Xiao, W., and $\mathrm{Hu}, \mathrm{N}$.: Determining the oxygen isotope composition of evapotranspiration using eddy covariance, Bound.-Lay. Meteorol., 137, 307-326, 2010.

Gu, L., Wood, J. D., Chang, C. Y.-Y., Sun, Y., and Riggs, J. S.: Advancing terrestrial ecosystem science with a novel automated measurement system for sun-induced chlorophyll fluorescence for integration with eddy covariance flux networks, J. Geophys. Res.-Biogeo., 124, 127-146, 2018.
Guzinski, R., Anderson, M. C., Kustas, W. P., Nieto, H., and Sandholt, I.: Using a thermal-based two source energy balance model with time-differencing to estimate surface energy fluxes with day-night MODIS observations, Hydrol. Earth Syst. Sci., 17, 2809-2825, https://doi.org/10.5194/hess-17-2809-2013, 2013.

Haghighi, E. and Or, D.: Thermal signatures of turbulent airflows interacting with evaporating thin porous surfaces, Int. J. Heat Mass Tran., 87, 429-446, 2015.

Han, D., Wang, G., Liu, T., Xue, B.-L., Kuczera, G., and Xu, X.: Hydroclimatic response of evapotranspiration partitioning to prolonged droughts in semiarid grassland, J. Hydrol., 563, 766-777, 2018.

Hanson, P. J., Amthor, J. S., Wullschleger, S. D., Wilson, K. B., Grant, R. F., Hartley, A., Hui, D., Hunt Jr., E. R., Johnson, D. W., Kimball, J. S., King, A. W., Luo, Y., McNulty, S. G., Sun, G., Thornton, P. E., Wang, S., Williams, M., Baldocchi, D. D., and Cushman, R. M.: Oak forest carbon and water simulations: Model intercomparisons and evaluations against independent data, Ecol. Monogr., 74, 443-489, 2004.

Hari, P., Mäkelä, A., and Pohja, T.: Surprising implications of the optimality hypothesis of stomatal regulation gain support in a field test, Funct. Plant Biol., 27, 77-80, https://doi.org/10.1071/PP99050, 2000.

Hemakumara, H. M., Chandrapala, L., and Moene, A. F.: Evapotranspiration fluxes over mixed vegetation areas measured from large aperture scintillometer, Agr. Water Manage., 58, 109-122, 2003.

Hill, A. C., Clyde Hill, A., and Littlefield, N.: Ozone. Effect on apparent photosynthesis, rate of transpiration, and stomatal closure in plants, Environ. Sci. Technol., 3, 52-56, 1969.

Hoffmann, H., Nieto, H., Jensen, R., Guzinski, R., Zarco-Tejada, P., and Friborg, T.: Estimating evaporation with thermal UAV data and two-source energy balance models, Hydrol. Earth Syst. Sci., 20, 697-713, https://doi.org/10.5194/hess-20-697-2016, 2016.

Hollinger, D. Y., Goltz, S. M., Davidson, E. A., Lee, J. T., Tu, K., and Valentine, H. T.: Seasonal patterns and environmental control of carbon dioxide and water vapour exchange in an ecotonal boreal forest, Glob. Change Biol., 5, 891-902, 1999.

Huete, A. R.: A soil-adjusted vegetation index (SAVI), Remote Sens. Environ., 25, 295-309, 1988.

Hulley, G., Hook, S., Fisher, J., and Lee, C.: ECOSTRESS, A NASA Earth-Ventures Instrument for studying links between the water cycle and plant health over the diurnal cycle, in: 2017 IEEE International Geoscience and Remote Sensing Symposium (IGARSS), Fort Worth, TX, USA, 2017.

Ishimwe, R., Abutaleb, K., and Ahmed, F.: Applications of thermal imaging in agriculture - A review, Adv. Remote Sens., 03, 128 140, 2014.

Jain, A. K. and Yang, X.: Modeling the effects of two different land cover change data sets on the carbon stocks of plants and soils in concert with $\mathrm{CO}_{2}$ and climate change, Global Biogeochem. $\mathrm{Cy}$., 19, GB2015, https://doi.org/10.1029/2004GB002349, 2005.

Jarvis, P. G.: The interpretation of the variations in leaf water potential and stomatal conductance found in canopies in the field, Philos. T. R. Soc. Lon. B, 273, 593-610, 1976.

Jarvis, P. G. and McNaughton, K. G.: Stomatal control of transpiration: Scaling up from leaf to region, in: Advances in Ecological Research, 15, 1-49, https://doi.org/10.1016/S00652504(08)60119-1, 1986. 
Jarvis, P. G., Massheder, J. M., Hale, S. E., Moncrieff, J. B., Rayment, M., and Scott, S. L.: Seasonal variation of carbon dioxide, water vapor, and energy exchanges of a boreal black spruce forest, J. Geophys. Res.-Atmos., 102, 28953-28966, 1997.

Jasechko, S., Sharp, Z. D., Gibson, J. J., Birks, S. J., Yi, Y., and Fawcett, P. J.: Terrestrial water fluxes dominated by transpiration, Nature, 496, 347-350, 2013.

Ji, P., Yuan, X., and Liang X.-Z.: Do lateral flows matter for the hyperresolution land surface modeling?, J. Geophys. Res.-Atmos., 122, 12077-12092, 2017.

Jocher, G., Löfvenius, M., De Simon, G., Hörnlund, T., Linder, S., Lundmark, T., Marshall, J., Nilsson, M. B., Näsholm, T., Tarvainen, L., Öquist, M., and Peichl, M.: Apparent winter $\mathrm{CO}_{2}$ uptake by a boreal forest due to decoupling, Agr. Forest Meteorol., 232, 23-34, 2017.

Jocher, G., Marshall, J., Nilsson, M. B., Linder, S., De Simon, G., Hörnlund, T., Lundmark, T., Näsholm, T., Löfvenius, M. O., Tarvainen, L., Wallin, G., and Peichl, M.: Impact of canopy decoupling and subcanopy advection on the annual carbon balance of a boreal scots pine forest as derived from eddy covariance, J. Geophys. Res.-Biogeo., 123, 303-325, 2018.

Jones, H. G.: Use of thermography for quantitative studies of spatial and temporal variation of stomatal conductance over leaf surfaces, Plant Cell Environ., 22, 1043-1055, 1999.

Jones, H. G.: Application of thermal imaging and infrared sensing in plant physiology and ecophysiology, in: Advances in Botanical Research, 107-163, https://doi.org/10.1016/S00652296(04)41003-9, 2004.

Jones, H. G., Stoll, M., Santos, T., de Sousa, C., Chaves, M. M., and Grant, O. M.: Use of infrared thermography for monitoring stomatal closure in the field: application to grapevine, J. Exp. Bot., 53, 2249-2260, 2002.

Jung, M., Koirala, S., Weber, U., Ichii, K., Gans, F., Camps-Valls, G., Papale, D., Schwalm, C., Tramontana, G., and Reichstein, M.: The FLUXCOM ensemble of global land-atmosphere energy fluxes, Scientific Data, 6, 74, https://doi.org/10.1038/s41597019-0076-8, 2019.

Kaisermann, A., Ogée, J., Sauze, J., Wohl, S., Jones, S. P., Gutierrez, A., and Wingate, L.: Disentangling the rates of carbonyl sulfide (COS) production and consumption and their dependency on soil properties across biomes and land use types, Atmos. Chem. Phys., 18, 9425-9440, https://doi.org/10.5194/acp18-9425-2018, 2018.

Katul, G., Porporato, A., and Oren, R.: Stochastic dynamics of plant-water interactions, Annu. Rev. Ecol. Evol. S., 38, 767-791, 2007.

Katul, G. G., Palmroth, S., and Oren, R.: Leaf stomatal responses to vapour pressure deficit under current and $\mathrm{CO}_{2}$-enriched atmosphere explained by the economics of gas exchange, Plant Cell Environ., 32, 968-979, 2009.

Katul, G. G., Oren, R., Manzoni, S., Higgins, C., and Parlange, M. B.: Evapotranspiration: A process driving mass transport and energy exchange in the soil-plant-atmosphere-climate system, Rev. Geophys., 50, RG3002, https://doi.org/10.1029/2011rg000366, 2012.

Keeling, C. D.: The concentration and isotopic abundances of atmospheric carbon dioxide in rural areas, Geochim. Cosmochim. Ac., 13, 322-334, 1958.
Kendall, C. and McDonnell, J. J.: Isotope Tracers in Catchment Hydrology, Elsevier, Amsterdam, the Netherlands, 2012.

Klosterhalfen, A., Graf, A., Brüggemann, N., Drüe, C., Esser, O., González-Dugo, M. P., Heinemann, G., Jacobs, C. M. J., Mauder, M., Moene, A. F., Ney, P., Pütz, T., Rebmann, C., Ramos Rodríguez, M., Scanlon, T. M., Schmidt, M., Steinbrecher, R., Thomas, C. K., Valler, V., Zeeman, M. J., and Vereecken, H.: Source partitioning of $\mathrm{H}_{2} \mathrm{O}$ and $\mathrm{CO}_{2}$ fluxes based on high-frequency eddy covariance data: a comparison between study sites, Biogeosciences, 16, 1111-1132, https://doi.org/10.5194/bg-16-1111-2019, 2019a.

Klosterhalfen, A., Moene, A. F., Schmidt, M., Scanlon, T. M., Vereecken, H., and Graf, A.: Sensitivity analysis of a source partitioning method for $\mathrm{H}_{2} \mathrm{O}$ and $\mathrm{CO}_{2}$ fluxes based on high frequency eddy covariance data: Findings from field data and large eddy simulations, Agr. Forest Meteorol., 265, 152-170, 2019b.

Köhler, P., Frankenberg, C., Magney, T. S., Guanter, L., Joiner, J., and Landgraf, J.: Global retrievals of solar-induced chlorophyll fluorescence with TROPOMI: First results and intersensor comparison to OCO-2, Geophys. Res. Lett., 45, 10456-10463, https://doi.org/10.1029/2018gl079031, 2018.

Kool, D., Agam, N., Lazarovitch, N., Heitman, J. L., Sauer, T. J., and Ben-Gal, A.: A review of approaches for evapotranspiration partitioning, Agr. Forest Meteorol., 184, 56-70, 2014.

Krinner, G., Viovy, N., de Noblet-Ducoudré, N., Ogée, J., Polcher, J., Friedlingstein, P., Ciais, P., Sitch, S., and Colin Prentice, I.: A dynamic global vegetation model for studies of the coupled atmosphere-biosphere system, Global Biogeochem. Cy., 19, GB1015, https://doi.org/10.1029/2003gb002199, 2005.

Kustas, W. P. and Norman, J. M.: Use of remote sensing for evapotranspiration monitoring over land surfaces, Hydrolog. Sci. J., 41, 495-516, 1996.

Kustas, W. P., Diak, G. R., and Norman, J. M.: Time difference methods for monitoring regional scale heat fluxes with remote sensing, in: Land Surface Hydrology, Meteorology, and Climate: Observations and Modeling, edited by: Lakshmi, V., Albertson, J., and Schaake, J., Water Science and Application Series, 3, 1529, 2001 .

Labat, D., Goddéris, Y., Probst, J. L., and Guyot, J. L.: Evidence for global runoff increase related to climate warming, Adv. Water Resour., 27, 631-642, 2004.

Lehmann, P., Assouline, S., and Or, D.: Characteristic lengths affecting evaporative drying of porous media, Phys. Rev. E, 77, 056309, https://doi.org/10.1103/PhysRevE.77.056309, 2008.

Lehmann, P., Merlin, O., Gentine, P., and Or, D.: Soil texture effects on surface resistance to bare soil evaporation, Geophys. Res. Lett., 45, 10398-10405, 2018.

Lemordant, L. and Gentine, P.: Vegetation response to rising $\mathrm{CO}_{2}$ impacts extreme temperatures, Geophys. Res. Lett., 46, 13831392, https://doi.org/10.1029/2018gl080238, 2018.

Lemordant, L., Gentine, P., Stéfanon, M., Drobinski, P., and Fatichi, S.: Modification of land-atmosphere interactions by $\mathrm{CO}_{2}$ effects: Implications for summer dryness and heat wave amplitude, Geophys. Res. Lett., 43, 10240-10248, 2016.

Leuning, R.: A critical appraisal of a combined stomatalphotosynthesis model for $\mathrm{C}_{3}$ plants, Plant Cell Environ., 18, 339355, 1995. 
Leuning, R., van Gorsel, E., Massman, W. J., and Isaac, P. R.: Reflections on the surface energy imbalance problem, Agr. Forest Meteorol., 156, 65-74, 2012.

Li, S., Wang, G., Sun, S., Chen, H., Bai, P., Zhou, S., Huang, Y., Wang, J., and Deng, P.: Assessment of multisource evapotranspiration products over China using eddy covariance observations, Remote Sens., 10, 1692, https://doi.org/10.3390/rs10111692, 2018.

Li, X., Gentine, P., Lin, C., Zhou, S., Sun, Z., Zheng, Y., Liu, J., and Zheng, C.: A simple and objective method to partition evapotranspiration into transpiration and evaporation at eddy-covariance sites, Agr. Forest Meteorol., 265, 171-182, 2019.

Lian, X., Piao, S., Huntingford, C., Li, Y., Zeng, Z., Wang, X., Ciais, P., McVicar, T. R., Peng, S., Ottlé, C., Yang, H., Yang, Y., Zhang, Y., and Wang, T.: Partitioning global land evapotranspiration using CMIP5 models constrained by observations, Nat. Clim. Change, 8, 640-646, https://doi.org/10.1038/s41558-0180207-9, 2018.

Lin, C., Gentine, P., Huang, Y., Guan, K., Kimm, H., and Zhou, S.: Diel ecosystem conductance response to vapor pressure deficit is suboptimal and independent of soil moisture, Agr. Forest Meteorol., 250-251, 24-34, 2018.

Linhoss, A. C. and Siegert, C. M.: A comparison of five forest interception models using global sensitivity and uncertainty analysis, J. Hydrol., 538, 109-116, 2016.

Liu, J., Chen, J. M., Cihlar, J., and Chen, W.: Net primary productivity distribution in the BOREAS region from a process model using satellite and surface data, J. Geophys. Res.-Atmos., 104, 27735-27754, 1999.

Liu, S.: Evaluation of the Liu model for predicting rainfall interception in forests world-wide, Hydrol. Process., 15, 2341-2360, 2001.

Liu, S., Riekerk, H., and Gholz, H. L.: Simulation of evapotranspiration from Florida pine flatwoods, Ecol. Model., 114, 19-34, 1998.

Lu, X., Liu, Z., An, S., Miralles, D. G., Maes, W., Liu, Y., and Tang, J.: Potential of solar-induced chlorophyll fluorescence to estimate transpiration in a temperate forest, Agr. Forest Meteorol., 252, 75-87, 2018.

Maes, W. H., Gentine, P., Verhoest, N. E. C., and Miralles, D. G.: Potential evaporation at eddy-covariance sites across the globe, Hydrol. Earth Syst. Sci., 23, 925-948, https://doi.org/10.5194/hess-23-925-2019, 2019.

Mammarella, I., Launiainen, S., Gronholm, T., Keronen, P., Pumpanen, J., Rannik, Ü., and Vesala, T.: Relative humidity effect on the high-frequency attenuation of water vapor flux measured by a closed-path eddy covariance system, J. Atmos. Ocean. Tech., 26, 1856-1866, 2009.

Mao, J., Fu, W., Shi, X., Ricciuto, D. M., Fisher, J. B., Dickinson, R. E., Wei, Y., Shem, W., Piao, S., Wang, K., Schwalm, C. R., Tian, H., Mu, M., Arain, A., Ciais, P., Cook, R., Dai, Y., Hayes, D., Hoffman, F. M., Huang, M., Huang, S., Huntzinger, D. N., Ito, A., Jain, A., King, A. W., Lei, H., Lu, C., Michalak, A. M., Parazoo, N., Peng, C., Peng, S., Poulter, B., Schaefer, K., Jafarov, E., Thornton, P. E., Wang, W., Zeng, N., Zeng, Z., Zhao, F., Zhu, Q., and Zhu, Z.: Disentangling climatic and anthropogenic controls on global terrestrial evapotranspiration trends, Environ. Res. Lett., 10, 094008, https://doi.org/10.1088/17489326/10/9/094008, 2015.
Martens, B., Miralles, D. G., Lievens, H., van der Schalie, R., de Jeu, R. A. M., Fernández-Prieto, D., Beck, H. E., Dorigo, W. A., and Verhoest, N. E. C.: GLEAM v3: satellite-based land evaporation and root-zone soil moisture, Geosci. Model Dev., 10, 19031925, https://doi.org/10.5194/gmd-10-1903-2017, 2017.

Maseyk, K., Berry, J. A., Billesbach, D., Campbell, J. E., Torn, M. S., Zahniser, M., and Seibt, U.: Sources and sinks of carbonyl sulfide in an agricultural field in the Southern Great Plains, P. Natl. Acad. Sci. USA, 111, 9064-9069, 2014.

Matheny, A. M., Bohrer, G., Stoy, P. C., Baker, I. T., Black, A. T., Desai, A. R., Dietze, M. C., Gough, C. M., Ivanov, V. Y., Jassal, R. S., Novick, K. A., Schäfer, K. V. R., and Verbeeck, H.: Characterizing the diurnal patterns of errors in the prediction of evapotranspiration by several land-surface models: An NACP analysis, J. Geophys. Res.-Biogeo., 119, 1458-1473, 2014.

Mathieu, R. and Bariac, T.: An Isotopic Study $\left({ }^{2} \mathrm{H}\right.$ and $\left.{ }^{18} \mathrm{O}\right)$ of Water Movements in Clayey Soils Under a Semiarid Climate, Water Resour. Res., 32, 779-789, 1996.

Maxwell, R. M. and Condon, L. E.: Connections between groundwater flow and transpiration partitioning, Science, 353, 377-380, 2016.

McCabe, M. F., Rodell, M., Alsdorf, D. E., Miralles, D. G., Uijlenhoet, R., Wagner, W., Lucieer, A., Houborg, R., Verhoest, N. E. C., Franz, T. E., Shi, J., Gao, H., and Wood, E. F.: The future of Earth observation in hydrology, Hydrol. Earth Syst. Sci., 21, 3879-3914, https://doi.org/10.5194/hess-21-3879-2017, 2017.

McNaughton, K. G. and Spriggs, T. W.: A mixed-layer model for regional evaporation, Bound.-Lay. Meteorol., 34, 243-262, 1986.

McVicar, T. R., Roderick, M. L., Donohue, R. J., Li, L. T., Van Niel, T. G., Thomas, A., Grieser, J., Jhajharia, D., Himri, Y., Mahowald, N. M., Mescherskaya, A. V., Kruger, A. C., Rehman, S., and Dinpashoh, Y.: Global review and synthesis of trends in observed terrestrial near-surface wind speeds: Implications for evaporation, J. Hydrol., 416-417, 182-205, 2012a.

McVicar, T. R., Roderick, M. L., Donohue, R. J., and Van Niel, T. G.: Less bluster ahead? Ecohydrological implications of global trends of terrestrial near-surface wind speeds, Ecohydrol., 5, 381-388, 2012b.

Medlyn, B. E., Duursma, R. A., Eamus, D., Ellsworth, D. S., Colin Prentice, I., Barton, C. V. M., Crous, K. Y., de Angelis, P., Freeman, M., and Wingate, L.: Reconciling the optimal and empirical approaches to modelling stomatal conductance, Glob. Change Biol., 17, 2134-2144, 2011.

Medlyn, B. E., De Kauwe, M. G., Lin, Y.-S., Knauer, J., Duursma, R. A., Williams, C. A., Arneth, A., Clement, R., Isaac, P., Limousin, J.-M., Linderson, M.-L., Meir, P., Martin-StPaul, N., and Wingate, L.: How do leaf and ecosystem measures of wateruse efficiency compare?, New Phytol., 216, 758-770, 2017.

Medrano, H., Tomás, M., Martorell, S., Flexas, J., Hernández, E., Rosselló, J., Pou, A., Escalona, J.-M., and Bota, J.: From leaf to whole-plant water use efficiency (WUE) in complex canopies: Limitations of leaf WUE as a selection target, The Crop Journal, 3, 220-228, 2015.

Medvigy, D., Wofsy, S. C., Munger, J. W., Hollinger, D. Y., and Moorcroft, P. R.: Mechanistic scaling of ecosystem function and dynamics in space and time: Ecosystem Demography model version 2, J. Geophys. Res., 114, G01002, https://doi.org/10.1029/2008jg000812, 2009. 
Mencuccini, M., Manzoni, S., and Christoffersen, B.: Modelling water fluxes in plants: from tissues to biosphere, New Phytol., 222, 1207-1222, https://doi.org/10.1111/nph.15681, 2019.

Merlin, O., Stefan, V. G., Amazirh, A., Chanzy, A., Ceschia, E., ErRaki, S., Gentine, P., Tallec, T., Ezzahar, J., Bircher, S., Beringer, J., and Khabba, S.: Modeling soil evaporation efficiency in a range of soil and atmospheric conditions using a meta-analysis approach, Water Resour. Res., 52, 3663-3684, 2016.

Merlin, O., Olivera-Guerra, L., Hssaine, B. A., Amazirh, A., Rafi, Z., Ezzahar, J., Gentine, P., Khabba, S., Gascoin, S., and Er-Raki, S.: A phenomenological model of soil evaporative efficiency using surface soil moisture and temperature data, Agr. Forest Meteorol., 256-257, 501-515, 2018.

Meroni, M., Rossini, M., Guanter, L., Alonso, L., Rascher, U., Colombo, R., and Moreno, J.: Remote sensing of solar-induced chlorophyll fluorescence: Review of methods and applications, Remote Sens. Environ., 113, 2037-2051, 2009.

Miralles, D. G., De Jeu, R. A. M., Gash, J. H., Holmes, T. R. H., and Dolman, A. J.: Magnitude and variability of land evaporation and its components at the global scale, Hydrol. Earth Syst. Sci., 15, 967-981, https://doi.org/10.5194/hess-15-967-2011, 2011a.

Miralles, D. G., Holmes, T. R. H., De Jeu, R. A. M., Gash, J. H., Meesters, A. G. C. A., and Dolman, A. J.: Global land-surface evaporation estimated from satellite-based observations, Hydrol. Earth Syst. Sci., 15, 453-469, https://doi.org/10.5194/hess-15453-2011, 2011b.

Misson, L., Baldocchi, D. D., Black, T. A., Blanken, P. D., Brunet, Y., Curiel Yuste, J., Dorsey, J. R., Falk, M., Granier, A., Irvine, M. R., Jarosz, N., Lamaud, E., Launiainen, S., Law, B. E., Longdoz, B., Loustau, D., McKay, M., Paw U, K. T., Vesala, T., Vickers, D., Wilson, K. B., and Goldstein, A. H.: Partitioning forest carbon fluxes with overstory and understory eddy-covariance measurements: A synthesis based on FLUXNET data, Agr. Forest Meteorol., 144, 14-31, 2007.

Monteith, J. L.: Evaporation and environment, Sym. Soc. Exp. Biol., 19, 205-234, 1965.

Montzka, S. A., Calvert, P., Hall, B. D., Elkins, J. W., Conway, T. J., Tans, P. P., and Sweeney, C.: On the global distribution, seasonality, and budget of atmospheric carbonyl sulfide (COS) and some similarities to $\mathrm{CO}_{2}$, J. Geophys. Res., 112, D09302, https://doi.org/10.1029/2006jd007665, 2007.

Moore, K. E., Fitzjarrald, D. R., Sakai, R. K., Goulden, M. L., Munger, J. W., and Wofsy, S. C.: Seasonal variation in radiative and turbulent exchange at a deciduous forest in central Massachusetts, J. Appl. Meteorol., 35, 122-134, 1996.

Moran, M. S., Susan Moran, M., Scott, R. L., Hamerlynck, E. P., Green, K. N., Emmerich, W. E., and Holifield Collins, C. D.: Soil evaporation response to Lehmann lovegrass (Eragrostis lehmanniana) invasion in a semiarid watershed, Agr. Forest Meteorol., 149, 2133-2142, 2009.

$\mathrm{Mu}$, Q., Zhao, M., and Running, S. W.: Improvements to a MODIS global terrestrial evapotranspiration algorithm, Remote Sens. Environ., 115, 1781-1800, 2011.

Mueller, B., Hirschi, M., Jimenez, C., Ciais, P., Dirmeyer, P. A., Dolman, A. J., Fisher, J. B., Jung, M., Ludwig, F., Maignan, F., Miralles, D. G., McCabe, M. F., Reichstein, M., Sheffield, J., Wang, K., Wood, E. F., Zhang, Y., and Seneviratne, S. I.: Benchmark products for land evapotranspiration: LandFlux-
EVAL multi-data set synthesis, Hydrol. Earth Syst. Sci., 17, 3707-3720, https://doi.org/10.5194/hess-17-3707-2013, 2013.

Nachshon, U., Shahraeeni, E., Or, D., Dragila, M., and Weisbrod, N.: Infrared thermography of evaporative fluxes and dynamics of salt deposition on heterogeneous porous surfaces, Water Resour. Res., 47, W12519, https://doi.org/10.1029/2011wr010776, 2011.

Nelson, J. A., Carvalhais, N., Cuntz, M., Delpierre, N., Knauer, J., Ogee, J., Migliavacca, M., Reichstein, M., and Jung, M.: Coupling water and carbon fluxes to constrain estimates of transpiration: the TEA algorithm, J. Geophys. Res.-Biogeo., 123, 36173632, https://doi.org/10.1029/2018jg004727, 2018.

Noone, D., Risi, C., Bailey, A., Berkelhammer, M., Brown, D. P., Buenning, N., Gregory, S., Nusbaumer, J., Schneider, D., Sykes, J., Vanderwende, B., Wong, J., Meillier, Y., and Wolfe, D.: Determining water sources in the boundary layer from tall tower profiles of water vapor and surface water isotope ratios after a snowstorm in Colorado, Atmos. Chem. Phys., 13, 1607-1623, https://doi.org/10.5194/acp-13-1607-2013, 2013.

Norman, J. M., Kustas, W. P., and Humes, K. S.: Source approach for estimating soil and vegetation energy fluxes in observations of directional radiometric surface temperature, Agr. Forest Meteorol., 77, 263-293, 1995.

Norman, J. M., Kustas, W. P., Prueger, J. H., and Diak, G. R.: Surface flux estimation using radiometric temperature: A dualtemperature-difference method to minimize measurement errors, Water Resour. Res., 36, 2263-2274, 2000.

Norman, J. M., Anderson, M. C., Kustas, W. P., French, A. N., Mecikalski, J., Torn, R., Diak, G. R., Schmugge, T. J., and Tanner, B. C. W.: Remote sensing of surface energy fluxes at 101-m pixel resolutions, Water Resour. Res., 39, 1221, https://doi.org/10.1029/2002wr001775, 2003.

Novick, K. A., Ficklin, D. L., Stoy, P. C., Williams, C. A., Bohrer, G., Christopher Oishi, A., Papuga, S. A., Blanken, P. D., Noormets, A., Sulman, B. N., Scott, R. L., Wang, L., and Phillips, R. P.: The increasing importance of atmospheric demand for ecosystem water and carbon fluxes, Nat. Clim. Change, 6, 1023-1027, 2016.

Oerter, E., Finstad, K., Schaefer, J., Goldsmith, G. R., Dawson, T., and Amundson, R.: Oxygen isotope fractionation effects in soil water via interaction with cations $(\mathrm{Mg}, \mathrm{Ca}, \mathrm{K}, \mathrm{Na})$ adsorbed to phyllosilicate clay minerals, J. Hydrol., 515, 1-9, 2014.

Oerter, E. J., Perelet, A., Pardyjak, E., and Bowen, G.: Membrane inlet laser spectroscopy to measure $\mathrm{H}$ and $\mathrm{O}$ stable isotope compositions of soil and sediment pore water with high sample throughput, Rapid Commun. Mass Sp., 31, 75-84, 2016.

Ogée, J., Cuntz, M., Peylin, P., and Bariac, T.: Non-steady-state, non-uniform transpiration rate and leaf anatomy effects on the progressive stable isotope enrichment of leaf water along monocot leaves, Plant Cell Environ., 30, 367-387, 2007.

Ohmura, A. and Wild, M.: Climate change. Is the hydrological cycle accelerating?, Science, 298, 1345-1346, 2002.

Oishi, A. C., Christopher Oishi, A., Oren, R., and Stoy, P. C.: Estimating components of forest evapotranspiration: A footprint approach for scaling sap flux measurements, Agr. Forest Meteorol., 148, 1719-1732, 2008.

Oki, T. and Kanae, S.: Global hydrological cycles and world water resources, Science, 313, 1068-1072, 2006. 
Or, D. and Lehmann, P.: Surface evaporative capacitance: How soil type and rainfall characteristics affect global-scale surface evaporation, Water Resour. Res., 55, 519-539, 2019.

Oren, R., Sperry, J. S., Katul, G. G., Pataki, D. E., Ewers, B. E., Phillips, N., and Schäfer, K. V. R.: Survey and synthesis of intraand interspecific variation in stomatal sensitivity to vapour pressure deficit, Plant Cell Environ., 22, 1515-1526, 1999.

Orlowski, N., Breuer, L., and McDonnell, J. J.: Critical issues with cryogenic extraction of soil water for stable isotope analysis, Ecohydrol., 9, 1-5, 2016a.

Orlowski, N., Pratt, D. L., and McDonnell, J. J.: Intercomparison of soil pore water extraction methods for stable isotope analysis, Hydrol. Process., 30, 3434-3449, 2016 b.

Pagán, B., Maes, W., Gentine, P., Martens, B., and Miralles, D.: Exploring the potential of satellite solar-induced fluorescence to constrain global transpiration estimates, Remote Sens., 11, 413, https://doi.org/10.3390/rs11040413, 2019.

Page, G. F. M., Liénard, J. F., Pruett, M. J., and Moffett, K. B.: Spatiotemporal dynamics of leaf transpiration quantified with timeseries thermal imaging, Agr. Forest Meteorol., 256-257, 304314, 2018.

Palatella, L., Rana, G., and Vitale, D.: Towards a flux-partitioning procedure based on the direct use of high-frequency eddycovariance data, Bound.-Lay. Meteorol., 153, 327-337, 2014.

Paschalis, A., Fatichi, S., Pappas, C., and Or, D.: Covariation of vegetation and climate constrains present and future T/ET variability, Environ. Res. Lett., 13, 104012, https://doi.org/10.1088/1748-9326/aae267, 2018.

Pau, S., Detto, M., Kim, Y., and Still, C. J.: Tropical forest temperature thresholds for gross primary productivity, Ecosphere, 9, e02311, https://doi.org/10.1002/ecs2.2311, 2018.

Paul-Limoges, E., Wolf, S., Eugster, W., Hörtnagl, L., and Buchmann, N.: Below-canopy contributions to ecosystem $\mathrm{CO}_{2}$ fluxes in a temperate mixed forest in Switzerland, Agr. Forest Meteorol., 247, 582-596, 2017.

Penman, H. L.: Natural evaporation from open water, bare soil and grass, P. Rpy. Soc. Lond. A Mat., 193, 120-145, 1948.

Pereira, F. L., Valente, F., David, J. S., Jackson, N., Minunno, F., and Gash, J. H.: Rainfall interception modelling: Is the wet bulb approach adequate to estimate mean evaporation rate from wet/saturated canopies in all forest types?, J. Hydrol., 534, 606615, 2016

Perez-Priego, O., El-Madany, T. S., Migliavacca, M., Kowalski, A. S., Jung, M., Carrara, A., Kolle, O., Pilar Martín, M., PachecoLabrador, J., Moreno, G., and Reichstein, M.: Evaluation of eddy covariance latent heat fluxes with independent lysimeter and sapflow estimates in a Mediterranean savannah ecosystem, Agr. Forest Meteorol., 236, 87-99, 2017.

Perez-Priego, O., Katul, G., Reichstein, M., El-Madany, T. S., Ahrens, B., Carrara, A., Scanlon, T. M., and Migliavacca, M.: Partitioning eddy covariance water flux components using physiological and micrometeorological approaches, J. Geophys. Res.-Biogeo., 123, 3353-3370, https://doi.org/10.1029/2018jg004637, 2018.

Phillips, D. L. and Gregg, J. W.: Uncertainty in source partitioning using stable isotopes, Oecologia, 127, 171-179, https://doi.org/10.1007/s004420000578, 2001.

Pieruschka, R., Huber, G., and Berry, J. A.: Control of transpiration by radiation, P. Natl. Acad. Sci. USA, 107, 13372-13377, 2010.
Polhamus, A., Fisher, J. B., and Tu, K. P.: What controls the error structure in evapotranspiration models?, Agr. Forest Meteorol., 169, 12-24, 2013.

Porporato, A., Daly, E., and Rodriguez-Iturbe, I.: Soil water balance and ecosystem response to climate change, Am. Nat., 164, 625632, https://doi.org/10.1086/424970, 2004.

Poyatos, R., Granda, V., Molowny-Horas, R., Mencuccini, M., Steppe, K., and Martínez-Vilalta, J.: SAPFLUXNET: towards a global database of sap flow measurements, Tree Physiol., 36, 1449-1455, 2016.

Priestley, C. H. B. and Taylor, R. J.: On the assessment of surface heat flux and evaporation using large-scale parameters, Mon. Weather Rev., 100, 81-92, 1972.

Probst, J. L. and Tardy, Y.: Long range streamflow and world continental runoff fluctuations since the beginning of this century, J. Hydrol., 94, 289-311, 1987.

Protoschill-Krebs, G., Wilhelm, C., and Kesselmeier, J.: Consumption of carbonyl sulphide (COS) by higher plant carbonic anhydrase (CA), Atmos. Environ., 30, 3151-3156, 1996.

Quade, M., Klosterhalfen, A., Graf, A., Brüggemann, N., Hermes, N., Vereecken, H., and Rothfuss, Y.: In-situ monitoring of soil water isotopic composition for partitioning of evapotranspiration during one growing season of sugar beet (Beta vulgaris), Agr. Forest Meteorol., 266-267, 53-64, 2019.

Rafi, Z., Merlin, O., Le Dantec, V., Khabba, S., Mordelet, P., ErRaki, S., Amazirh, A., Olivera-Guerra, L., Ait Hssaine, B., Simonneaux, V., Ezzahar, J., and Ferrer, F.: Partitioning evapotranspiration of a drip-irrigated wheat crop: Inter-comparing eddy covariance-, sap flow-, lysimeter- and FAO-based methods, Agr. Forest Meteorol., 265, 310-326, 2019.

Rana, G., Palatella, L., Scanlon, T. M., Martinelli, N., and Ferrara, R. M.: $\mathrm{CO}_{2}$ and $\mathrm{H}_{2} \mathrm{O}$ flux partitioning in a Mediterranean cropping system, Agr. Forest Meteorol., 260-261, 118-130, 2018.

Raz-Yaseef, N., Rotenberg, E., and Yakir D.: Deep learning and process understanding for data-driven Earth system science, Agr. Forest Meteorol., 150, 454-462, 2010.

Reichstein, M., Camps-Valls, G., Stevens, B., Jung, M., Denzler, J., Carvalhais, N., and Prabhat: Deep learning and process understanding for data-driven Earth system science, Nature, 566, 195-204, 2019.

Ricciuto, D. M., Schaefer, K., Thornton, P. E., Davis, K. J., Cook, R. B., Liu, S., Anderson, R., Arain, M. A., Baker, I. T., Chen, J. M., Dietze, M., Grant, R., Izaurralde, C., Jain, A. K., King, A. W., Kucharik, C. J., Liu, S., Lokupitiya, E., Luo, Y., Peng, C., Poulter, B., Price, D., Riley, W., Sahoo, A., Tian, H., Tonitto, C., and Verbeeck, H.: NACP Site: Terrestrial biosphere model and aggregated flux data in standard format, ORNL DAAC, https://doi.org/10.3334/ORNLDAAC/1183, 2013.

Rigden, A. J. and Salvucci, G. D.: Evapotranspiration based on equilibrated relative humidity (ETRHEQ): Evaluation over the continental U.S., Water Resour. Res., 51, 2951-2973, 2015.

Rigden, A. J. and Salvucci, G. D.: Stomatal response to humidity and $\mathrm{CO}_{2}$ implicated in recent decline in US evaporation, Glob. Change Biol., 23, 1140-1151, 2016.

Rigden, A. J., Salvucci, G. D., Entekhabi, D., and Short Gianotti, D. J.: Partitioning evapotranspiration over the continental United States using weather station data, Geophys. Res. Lett., 45, 96059613, 2018. 
Riley, W. J., Still, C. J., Torn, M. S., and Berry, J. A.: A mechanistic model of $\mathrm{H}_{2}^{18} \mathrm{O}$ and $\mathrm{C}^{18} \mathrm{OO}$ fluxes between ecosystems and the atmosphere: Model description and sensitivity analyses, Global Biogeochem. Cy., 16, 42-1-42-14, 2002.

Rogers, A., Medlyn, B. E., Dukes, J. S., Bonan, G., von Caemmerer, S., Dietze, M. C., Kattge, J., Leakey A. D. B., Mercado L. M., Niinemets Ü, Prentice, I. C., Serbin, S. P., Stitch, S., Way, D. A., and Zaehle, S.: A roadmap for improving the representation of photosynthesis in Earth system models, New Phytol., 213, 2242, 2017.

Ruddell, B. L., Brunsell, N. A., and Stoy, P.: Applying information theory in the geosciences to quantify process uncertainty, feedback, scale, EOS T. Am. Geophys. Un., 94, 56-56, 2013.

Rutter, A., Kershaw, K., Robins, P., and Morton, A.: A predictive model of rainfall interception in forests, 1 . Derivation of the model from observations in a plantation of Corsican pine, Agr. Meteorol., 9, 367-384, 1971.

Salvucci, G. D. and Gentine, P.: Emergent relation between surface vapor conductance and relative humidity profiles yields evaporation rates from weather data, P. Natl. Acad. Sci. USA, 110, 6287-6291, 2013.

Sandoval-Soto, L., Stanimirov, M., von Hobe, M., Schmitt, V., Valdes, J., Wild, A., and Kesselmeier, J.: Global uptake of carbonyl sulfide (COS) by terrestrial vegetation: Estimates corrected by deposition velocities normalized to the uptake of carbon dioxide $\left(\mathrm{CO}_{2}\right)$, Biogeosciences, 2, 125-132, https://doi.org/10.5194/bg-2-125-2005, 2005.

Santos, D. M., Acevedo, O. C., Chamecki, M., Fuentes, J. D., Gerken, T., and Stoy, P. C.: Temporal scales of the nocturnal flow within and above a forest canopy in Amazonia, Bound.-Lay. Meteorol., 161, 73-98, 2016.

Scanlon, T. M. and Kustas, W. P.: Partitioning carbon dioxide and water vapor fluxes using correlation analysis, Agr. Forest Meteorol., 150, 89-99, 2010.

Scanlon, T. M. and Kustas, W. P.: Partitioning evapotranspiration using an eddy covariance-based technique: Improved assessment of soil moisture and land-atmosphere exchange dynamics, Vadose Zone J., 11, https://doi.org/10.2136/vzj2012.0025, 2012.

Scanlon, T. M. and Sahu, P.: On the correlation structure of water vapor and carbon dioxide in the atmospheric surface layer: A basis for flux partitioning, Water Resour. Res., 44, W10418, https://doi.org/10.1029/2008wr006932, 2008.

Schaefer, K., Zhang, T., Slater, A. G., Lu, L., Etringer, A., and Baker, I.: Improving simulated soil temperatures and soil freeze/thaw at high-latitude regions in the Simple Biosphere/Carnegie-Ames-Stanford Approach model, J. Geophys. Res., 114, F02021, https://doi.org/10.1029/2008jf001125, 2009.

Schäfer, K. V. R.: Canopy stomatal conductance following drought, disturbance, and death in an upland oak/pine forest of the New Jersey Pine Barrens, USA, Front. Plant Sci., 2, 15, https://doi.org/10.3389/fpls.2011.00015, 2011.

Schellekens, J., Scatena, F. N., Bruijnzeel, L. A., and Wickel, A. J.: Modelling rainfall interception by a lowland tropical rain forest in northeastern Puerto Rico, J. Hydrol., 225, 168-184, 1999.

Schilperoort, B., Coenders-Gerrits, M., Luxemburg, W., Jiménez Rodríguez, C., Cisneros Vaca, C., and Savenije, H.: Technical note: Using distributed temperature sensing for Bowen ra- tio evaporation measurements, Hydrol. Earth Syst. Sci., 22, 819830, https://doi.org/10.5194/hess-22-819-2018, 2018.

Schlesinger, W. H. and Jasechko, S.: Transpiration in the global water cycle, Agr. Forest Meteorol., 189-190, 115-117, 2014.

Schwalm, C. R., Black, T. A., Morgenstern, K., and Humphreys, E. R.: A method for deriving net primary productivity and component respiratory fluxes from tower-based eddy covariance data: a case study using a 17-year data record from a Douglas-fir chronosequence, Glob. Change Biol., 13, 370-385, 2007.

Schwalm, C. R., Williams, C. A., Schaefer, K., Anderson, R., Arain, M. A., Baker, I., Barr, A., Black, T. A., Chen, G., Chen, J. M., Ciais, P., Davis, K. J., Desai, A., Dietze, M., Dragoni, D., Fischer, M. L., Flanagan, L. B., Grant, R., Gu, L., Hollinger, D., Izaurralde, R. C., Kucharik, C., Lafleur, P., Law, B. E., Li, L., Li, Z., Liu, S., Lokupitiya, E., Luo, Y., Ma, S., Margolis, H., Matamala, R., McCaughey, H., Monson, R. K., Oechel, W. C., Peng, C., Poulter, B., Price, D. T., Riciutto, D. M., Riley, W., Sahoo, A. K., Sprintsin, M., Sun, J., Tian, H., Tonitto, C., Verbeeck, H., and Verma, S. B.: A model-data intercomparison of $\mathrm{CO}_{2}$ exchange across North America: Results from the North American Carbon Program site synthesis, J. Geophys. Res., 115, 33623, https://doi.org/10.1029/2009JG001229, 2010.

Schymanski, S. J., Roderick, M. L., Sivapalan, M., Hutley, L. B., and Beringer, J.: A test of the optimality approach to modelling canopy properties and $\mathrm{CO}_{2}$ uptake by natural vegetation, Plant Cell Environ., 30, 1586-1598, 2007.

Schyns, J. F., Hoekstra, A. Y., Booij, M. J., Hogeboom, R. J., and Mekonnen, M. M.: Limits to the world's green water resources for food, feed, fiber, timber, and bioenergy, P. Natl. Acad. Sci. USA, 136, 201817380 , https://doi.org/10.1073/pnas.1817380116, 2019.

Scott, R. L. and Biederman, J. A.: Partitioning evapotranspiration using long-term carbon dioxide and water vapor fluxes, Geophys. Res. Lett., 44, 6833-6840, 2017.

Seibt, U., Kesselmeier, J., Sandoval-Soto, L., Kuhn, U., and Berry, J. A.: A kinetic analysis of leaf uptake of COS and its relation to transpiration, photosynthesis and carbon isotope fractionation, Biogeosciences, 7, 333-341, https://doi.org/10.5194/bg-7333-2010, 2010.

Semmens, K. A., Anderson, M. C., Kustas, W. P., Gao, F., Alfieri, J. G., McKee, L., Prueger, J. H., Hain, C. R., Cammalleri, C., Yang, Y., Xia, T., Sanchez, L., Alsina, M. M., and Vélez, M.: Monitoring daily evapotranspiration over two California vineyards using Landsat 8 in a multi-sensor data fusion approach, Remote Sens. Environ., 185, 155-170, 2016.

Shahraeeni, E. and Or, D.: Thermo-evaporative fluxes from heterogeneous porous surfaces resolved by infrared thermography, Water Resour. Res., 46, W09511, https://doi.org/10.1029/2009wr008455, 2010.

Shan, N., Ju, W., Migliavacca, M., Martini, D., Guanter, L., Chen, J., Goulas, Y., and Zhang, Y.: Modeling canopy conductance and transpiration from solar-induced chlorophyll fluorescence, Agr. Forest Meteorol., 268, 189-201, 2019.

Shrestha, P., Sulis, M., Simmer, C., and Kollet, S.: Effects of horizontal grid resolution on evapotranspiration partitioning using TerrSysMP, J. Hydrol., 557, 910-915, 2018.

Shuttleworth, W. J.: Putting the "vap" into evaporation, Hydrol. Earth Syst. Sci., 11, 210-244, https://doi.org/10.5194/hess-11210-2007, 2007. 
Siqueira, M., Katul, G., and Porporato, A.: Onset of water stress, hysteresis in plant conductance, and hydraulic lift: Scaling soil water dynamics from millimeters to meters, Water Resour. Res., 44, 1107, https://doi.org/10.1029/2007WR006094, 2008.

Skaggs, T. H., Anderson, R. G., Alfieri, J. G., Scanlon, T. M., and Kustas, W. P.: Fluxpart: Open source software for partitioning carbon dioxide and water vapor fluxes, Agr. Forest Meteorol., 253-254, 218-224, 2018.

Snyder, R. L., Spano, D., and Pawu, K. T.: Surface renewal analysis for sensible and latent heat flux density, Bound.-Lay. Meteorol., 77, 249-266, 1996.

Soderberg, K., Good, S. P., Wang, L., and Caylor, K.: Stable isotopes of water vapor in the vadose zone: A review of measurement and modeling techniques, Vadose Zone J., 11, https://doi.org/10.2136/vzj2011.0165, 2013.

Song, L., Liu, S., Kustas, W. P., Nieto, H., Sun, L., Xu, Z., Skaggs, T. H., Yang, Y., Ma, M., Xu, T., Tang, X., and Li, Q.: Monitoring and validating spatially and temporally continuous daily evaporation and transpiration at river basin scale, Remote Sens. Environ., 219, 72-88, 2018.

Spielmann, F. M., Wohlfahrt, G., Hammerle, A., Kitz, F., Migliavacca, M., Alberti, G., Ibrom, A., El-Madany, T. S., Gerdel, K., Moreno, G., Kolle, O., Karl, T., Peressoti, A., and Delle Vedove, G.: Gross primary productivity of four European ecosystems constrained by joint $\mathrm{CO}_{2}$ and COS flux measurements, Geophys. Res. Lett., 46, 5284-5293, https://doi.org/10.1029/2019GL082006, 2019.

Stoy, P. C., Katul, G. G., Siqueira, M. B. S., Juang, J.-Y., Novick, K. A., McCarthy, H. R., Christopher Oishi, A., Uebelherr, J. M., Kim, H.-S., and Oren, R.: Separating the effects of climate and vegetation on evapotranspiration along a successional chronosequence in the southeastern US, Glob. Change Biol., 12, 21152135, 2006.

Stoy, P. C., Mauder, M., Foken, T., Marcolla, B., Boegh, E., Ibrom, A., Arain, M. A., Arneth, A., Aurela, M., Bernhofer, C., Cescatti, A., Dellwik, E., Duce, P., Gianelle, D., van Gorsel, E., Kiely, G., Knohl, A., Margolis, H., McCaughey, H., Merbold, L., Montagnani, L., Papale, D., Reichstein, M., Saunders, M., Serrano-Ortiz, P., Sottocornola, M., Spano, D., Vaccari, F., and Varlagin, A.: A data-driven analysis of energy balance closure across FLUXNET research sites: The role of landscape scale heterogeneity, Agr. Forest Meteorol., 171-172, 137-152, 2013.

$\mathrm{Su}, \mathrm{Z}$.: The Surface Energy Balance System (SEBS) for estimation of turbulent heat fluxes, Hydrol. Earth Syst. Sci., 6, 85-100, https://doi.org/10.5194/hess-6-85-2002, 2002.

Sulman, B. N., Tyler Roman, D., Scanlon, T. M., Wang, L., and Novick, K. A.: Comparing methods for partitioning a decade of carbon dioxide and water vapor fluxes in a temperate forest, Agr. Forest Meteorol., 226-227, 229-245, 2016.

Sun, W., Maseyk, K., Lett, C., and Seibt, U.: Stomatal control of leaf fluxes of carbonyl sulfide and $\mathrm{CO}_{2}$ in a Typha freshwater marsh, Biogeosciences, 15, 3277-3291, https://doi.org/10.5194/bg-153277-2018, 2018.

Sutanto, S. J., van den Hurk, B., Dirmeyer, P. A., Seneviratne, S. I., Röckmann, T., Trenberth, K. E., Blyth, E. M., Wenninger, J., and Hoffmann, G.: HESS Opinions "A perspective on isotope versus non-isotope approaches to determine the contribution of transpiration to total evaporation", Hydrol. Earth Syst. Sci., 18, 2815-2827, https://doi.org/10.5194/hess-18-2815-2014, 2014.
Talsma, C. J., Good, S. P., Jimenez, C., Martens, B., Fisher, J. B., Miralles, D. G., McCabe, M. F., and Purdy, A. J.: Partitioning of evapotranspiration in remote sensing-based models, Agr. Forest Meteorol., 260-261, 131-143, 2018.

Thomas, C., Martin, J. G., Goeckede, M., Siqueira, M. B., Foken, T., Law, B. E., Loescher, H. W., and Katul, G.: Estimating daytime subcanopy respiration from conditional sampling methods applied to multi-scalar high frequency turbulence time series, Agr. Forest Meteorol., 148, 1210-1229, 2008.

Thomas, C. K., Law, B. E., Irvine, J., Martin, J. G., Cory Pettijohn, J., and Davis, K. J.: Seasonal hydrology explains interannual and seasonal variation in carbon and water exchange in a semiarid mature ponderosa pine forest in central Oregon, J. Geophys. Res., 114, G04006, https://doi.org/10.1029/2009jg001010, 2009.

Thomas, C. K., Martin, J. G., Law, B. E., and Davis, K.: Toward biologically meaningful net carbon exchange estimates for tall, dense canopies: Multi-level eddy covariance observations and canopy coupling regimes in a mature Douglas-fir forest in Oregon, Agr. Forest Meteorol., 173, 14-27, 2013.

Vadivambal, R. and Jayas, D. S.: Applications of thermal imaging in agriculture and food industry - A review, Food Bioprocess Tech., 4, 186-199, 2010.

van Dijk, A. I. J. M., Gash, J. H., van Gorsel, E., Blanken, P. D., Cescatti, A., Emmel, C., Gielen, B., Harman, I. N., Kiely, G., Merbold, L., Montagnani, L., Moors, E., Sottocornola, M., Varlagin, A., Williams, C. A., and Wohlfahrt, G.: Rainfall interception and the coupled surface water and energy balance, Agr. Forest Meteorol., 214-215, 402-415, 2015.

Vautard, R., Cattiaux, J., Yiou, P., Thépaut, J.-N., and Ciais, P.: Northern Hemisphere atmospheric stilling partly attributed to an increase in surface roughness, Nat. Geosci., 3, 756-761, 2010.

Vick, E. S. K., Stoy, P. C., Tang, A. C. I., and Gerken, T.: The surface-atmosphere exchange of carbon dioxide, water, and sensible heat across a dryland wheat-fallow rotation, Agr. Ecosyst. Environ., 232, 129-140, 2016.

Vinukollu, R. K., Meynadier, R., Sheffield, J., and Wood, E. F.: Multi-model, multi-sensor estimates of global evapotranspiration: climatology, uncertainties and trends, Hydrol. Process., 25, 3993-4010, 2011.

Volkmann, T. H. M. and Weiler, M.: Continual in situ monitoring of pore water stable isotopes in the subsurface, Hydrol. Earth Syst. Sci., 18, 1819-1833, https://doi.org/10.5194/hess-18-1819-2014, 2014.

Wang, D., Wang, G., and Anagnostou, E. N.: Evaluation of canopy interception schemes in land surface models, J. Hydrol., 347, 308-318, 2007.

Wang, K. and Dickinson, R. E.: A review of global terrestrial evapotranspiration: Observation, modeling, climatology, and climatic variability, Rev. Geophys., 50, RG2005, https://doi.org/10.1029/2011rg000373, 2012.

Wang, L., Good, S. P., and Caylor, K. K.: Global synthesis of vegetation control on evapotranspiration partitioning, Geophys. Res. Lett., 41, 6753-6757, 2014.

Wang, P., Li, X.-Y., Wang, L., Wu, X., Hu, X., Fan, Y., and Tong, Y.: Divergent evapotranspiration partition dynamics between shrubs and grasses in a shrub-encroached steppe ecosystem, New Phytol., 219, 1325-1337, 2018. 
Wehr, R., Commane, R., Munger, J. W., McManus, J. B., Nelson, D. D., Zahniser, M. S., Saleska, S. R., and Wofsy, S. C.: Dynamics of canopy stomatal conductance, transpiration, and evaporation in a temperate deciduous forest, validated by carbonyl sulfide uptake, Biogeosciences, 14, 389-401, https://doi.org/10.5194/bg14-389-2017, 2017.

Wei, Z., Yishimura, K., Okazaki, A., Kim, W., Liu, Z., and, Yokoi, M.: Partitioning of evapotranspiration using high-frequency water vapor isotopic measurement over a rice paddy field, Water Resour. Res., 51, 3716-3729, 2015.

Wei, Z., Yoshimura, K., Wang, L., Miralles, D. G., Jasechko, S., and Lee, X.: Revisiting the contribution of transpiration to global terrestrial evapotranspiration, Geophys. Res. Lett., 44, 2792-2801, 2017.

Wei, Z., Lee, X., Wen, X., and Xiao, W.: Evapotranspiration partitioning for three agro-ecosystems with contrasting moisture conditions: a comparison of an isotope method and a two-source model calculation, Agr. Forest Meteorol., 252, 296-310, 2018.

Wei, Z., Lee, X., Aemisegger, F., Benetti, M., Berkelhammer, M., Casado, M., Caylor, K., Christner, E., Dyroff, C., García, O., González, Y., Griffis, T., Kurita, N., Liang, J., Liang, M.-C., Lin, G., Noone, D., Gribanov, K., Munksgaard, N. C., Schneider, M., Ritter, F., Steen-Larsen, H. C., Vallet-Coulomb, C., Wen, X., Wright, J. S., Xiao, W., and Yoshimura, K.: A global database of water vapor isotopes measured with high temporal resolution infrared laser spectroscopy, Scientific Data, 6, 180302, https://doi.org/10.1038/sdata.2018.302, 2019.

Welp, L. R., Lee, X., Griffis, T. J., Wen, X.-F., Xiao, W., Li, S., Sun, X., Hu, Z., Martin, M. V., and Huang, J.: A metaanalysis of water vapor deuterium-excess in the midlatitude atmospheric surface layer, Global Biogeochem. Cy., 26, GB3021, https://doi.org/10.1029/2011gb004246, 2012.

Weng, E. and Luo, Y.: Soil hydrological properties regulate grassland ecosystem responses to multifactor global change: A modeling analysis, J. Geophys. Res., 113, G03003, https://doi.org/10.1029/2007jg000539, 2008.

Whelan, M. E., Hilton, T. W., Berry, J. A., Berkelhammer, M., Desai, A. R., and Campbell, J. E.: Carbonyl sulfide exchange in soils for better estimates of ecosystem carbon uptake, Atmos. Chem. Phys., 16, 3711-3726, https://doi.org/10.5194/acp16-3711-2016, 2016.

Whelan, M. E., Lennartz, S. T., Gimeno, T. E., Wehr, R., Wohlfahrt, G., Wang, Y., Kooijmans, L. M. J., Hilton, T. W., Belviso, S., Peylin, P., Commane, R., Sun, W., Chen, H., Kuai, L., Mammarella, I., Maseyk, K., Berkelhammer, M., Li, K.-F., Yakir, D., Zumkehr, A., Katayama, Y., Ogée, J., Spielmann, F. M., Kitz, F., Rastogi, B., Kesselmeier, J., Marshall, J., Erkkilä, K.-M., Wingate, L., Meredith, L. K., He, W., Bunk, R., Launois, T., Vesala, T., Schmidt, J. A., Fichot, C. G., Seibt, U., Saleska, S., Saltzman, E. S., Montzka, S. A., Berry, J. A., and Campbell, J. E.: Reviews and syntheses: Carbonyl sulfide as a multi-scale tracer for carbon and water cycles, Biogeosciences, 15, 36253657, https://doi.org/10.5194/bg-15-3625-2018, 2018.

Wild, M., Gilgen, H., Roesch, A., Ohmura, A., Long, C. N., Dutton, E. G., Forgan, B., Kallis, A., Russak, V., and Tsvetkov, A.: From dimming to brightening: decadal changes in solar radiation at Earth's surface, Science, 308, 847-850, 2005.
Willett, K. M., Jones, P. D., Gillett, N. P., and Thorne, P. W.: Recent changes in surface humidity: Development of the HadCRUH dataset, J. Climate, 21, 5364-5383, 2008.

Williams, D. G., Cable, W., Hultine, K., Hoedjes, J. C. B., Yepez, E. A., Simonneaux, V., Er-Raki, S., Boulet, G., de Bruin, H. A. R., Chehbouni, A., Hartogensis, O. K., and Timouk, F.: Evapotranspiration components determined by stable isotope, sap flow and eddy covariance techniques, Agr. Forest Meteorol., 125, 241258, 2004.

Williams, M., Richardson, A. D., Reichstein, M., Stoy, P. C., Peylin, P., Verbeeck, H., Carvalhais, N., Jung, M., Hollinger, D. Y., Kattge, J., Leuning, R., Luo, Y., Tomelleri, E., Trudinger, C. M., and Wang, Y.-P.: Improving land surface models with FLUXNET data, Biogeosciences, 6, 1341-1359, https://doi.org/10.5194/bg6-1341-2009, 2009.

Williamson, T. B., Price, D. T., Beverley, J. L., Bothwell, P. M., Frenkel, B., Park, J., and Patriquin, M. N.: Assessing potential biophysical and socioeconomic impacts of climate change on forest-based communities: a methodological case study, Natural Resources Canada, Canadian Forest Service, Edmonton, ABInf. Rep. NOR-X-415E, 2008.

Wilson, K. B., Hanson, P. J., Mulholland, P. J., Baldocchi, D. D., and Wullschleger, S. D.: A comparison of methods for determining forest evapotranspiration and its components: sap-flow, soil water budget, eddy covariance and catchment water balance, Agr. Forest Meteorol., 106, 153-168, 2001.

Wittig, V. E., Ainsworth, E. A., and Long, S. P.: To what extent do current and projected increases in surface ozone affect photosynthesis and stomatal conductance of trees? A meta-analytic review of the last 3 decades of experiments, Plant Cell Environ., 30, 1150-1162, 2007.

Wohlfahrt, G., Bianchi, K., and Cernusca, A.: Leaf and stem maximum water storage capacity of herbaceous plants in a mountain meadow, J. Hydrol., 319, 383-390, 2006.

Wohlfahrt, G., Haslwanter, A., Hörtnagl, L., Jasoni, R. L., Fenstermaker, L. F., Arnone III, J. A., and Hammerle, A.: On the consequences of the energy imbalance for calculating surface conductance to water vapour, Agr. Forest Meteorol., 149, 1556-1559, 2009.

Wohlfahrt, G., Brilli, F., Hörtnagl, L., Xu, X., Bingemer, H., Hansel, A., and Loreto, F.: Carbonyl sulfide (COS) as a tracer for canopy photosynthesis, transpiration and stomatal conductance: potential and limitations, Plant Cell Environ., 35, 657-667, 2012.

Yakir, D. and Sternberg, L. da S. L.: The use of stable isotopes to study ecosystem gas exchange, Oecologia, 123, 297-311, 2000.

Yang, F., Qubaja, R., Tatarinov, F., Rotenberg, E., and Yakir, D.: Assessing canopy performance using carbonyl sulfide measurements, Glob. Change Biol., 24, 3486-3498, 2018.

Yepez, E. A., Huxman, T. E., Ignace, D. D., English, N. B., Weltzin, J. F., Castellanos, A. E., and Williams, D. G.: Dynamics of transpiration and evaporation following a moisture pulse in semiarid grassland: A chamber-based isotope method for partitioning flux components, Agr. Forest Meteorol., 132, 359-376, 2005.

Young-Robertson, J. M., Raz-Yaseef, N., Cohen, L. R., Newman, B., Rahn, T., Sloan, V., Wilson, C., and Wullschleger, S. D.: Evaporation dominates evapotranspiration on Alaska's Arctic Coastal Plain, Arct. Antarct. Alp. Res., 50, e1435931, https://doi.org/10.1080/15230430.2018.1435931, 2018. 
Zeng, Z., Piao, S., Li, L. Z. X., Wang, T., Ciais, P., Lian, X., Yang, Y., Mao, J., Shi, X., and Myneni, R. B.: Impact of earth greening on the terrestrial water cycle, J. Climate, 31, 2633-2650, 2018.

Zhan, X., Xue, Y., and Collatz, J. G.: An analytical approach for estimating $\mathrm{CO}_{2}$ and heat fluxes over the Amazonian region, Ecol. Model., 162, 97-117, 2003.

Zhang, Y., Guanter, L., Berry, J. A., Joiner, J., van der Tol, C., Huete, A., Gitelson, A., Voigt, M., and Köhler, P.: Estimation of vegetation photosynthetic capacity from space-based measurements of chlorophyll fluorescence for terrestrial biosphere models, Glob. Change Biol., 20, 3727-3742, 2014

Zhang, Y., Peña-Arancibia, J. L., McVicar, T. R., Chiew, F. H. S., Vaze, J., Liu, C., Lu, X., Zheng, H., Wang, Y., Liu, Y. Y., Miralles, D. G., and Pan, M.: Multi-decadal trends in global terrestrial evapotranspiration and its components, Sci. Rep. UK, 6, 19124, https://doi.org/10.1038/srep19124, 2016.

Zhou, S., Yu, B., Huang, Y., and Wang, G.: The effect of vapor pressure deficit on water use efficiency at the subdaily time scale, Geophys. Res. Lett., 41, 5005-5013, 2014.
Zhou, S., Yu, B., Huang, Y., and Wang, G.: Daily underlying water use efficiency for AmeriFlux sites, J. Geophys. Res.-Biogeo., 120, 887-902, 2015.

Zhou, S., Yu, B., Zhang, Y., Huang, Y., and Wang, G.: Partitioning evapotranspiration based on the concept of underlying water use efficiency, Water Resour. Res., 52, 1160-1175, 2016.

Zhou, S., Yu, B., Zhang, Y., Huang, Y., and Wang, G.: Water use efficiency and evapotranspiration partitioning for three typical ecosystems in the Heihe River Basin, northwestern China, Agr. Forest Meteorol., 253-254, 261-273, 2018.

Zhou, S., Zhang, Y., Park Williams, A., and Gentine, P.: Projected increases in intensity, frequency, and terrestrial carbon costs of compound drought and aridity events, Science Advances, 5, eaau5740, https://doi.org/10.1126/sciadv.aau5740, 2019.

Zribi, M., Motte, E., Baghdadi, N., Baup, F., Dayau, S., Fanise, P., Guyon, D., Huc, M., and Wigneron, J.: Potential Applications of GNSS-R Observations over Agricultural Areas: Results from the GLORI Airborne Campaign, Remote Sens., 10, 1245, https://doi.org/10.3390/rs10081245, 2018. 